\title{
Highly Regioselective Monoacylation of Unprotected Glucopyranoside using Transient Directing-Protecting Groups
}

Sylvain Rocheleau, Joshua Pottel, Igor Huskić, Nicolas Moitessier*[a] Abstract: Regioselective functionalization of monosaccharides is notoriously achieved using metal catalysis, lengthy protection/deprotection-requiring synthetic strategies, various enzymes, or other methods that target cis-diols - all of which preclude their use with glucose derivatives. We report herein a new methodology using selected boronic acids as temporary protecting groups and describe its application to the regioselective functionalization of methyl $\alpha-\mathrm{D}-$ glucopyranoside, glucopyranosides being the most difficult to regioselectively functionalize. Generally, the reaction of glucopyranosides may lead to a plethora of mono- and polyfunctionalized derivatives, yet our methodology afforded the 3-O-acetylated, the 2-Obenzoylated and the 2-O-pivaloylated isomers of methyl $\alpha$-D-glucopyranoside as major products. Focus was put on the use of recyclable and green temporary protecting groups (in a one-pot reaction) and modulation of the intramolecular hydrogen bond network using specifically selected arylboronic acids. A complete scalable procedure leading to a single regioisomer from non-protected methyl $\alpha$-D-glucopyranoside is presented.

\section{Introduction}

Polysaccharides are multifunctional in nature, playing crucial roles ranging from being the major components of cell walls in plants to energy storage. A number of polysaccharides have also been reported as effective vaccine ${ }^{[1]}$ or drugs (e.g., Fondaparinux $\left.{ }^{[2]}\right){ }^{[3]}$ However, the complex structure of these biopolymers stipulates significant effort in their total synthesis ${ }^{[4]}$ a hurdle to large-scale production that can nonetheless be overcome. ${ }^{[5]}$ Access to these polymeric molecules is made possible primarily through the use of judicious protection strategies that must be devised to prepare the building blocks (i.e., monosaccharides) leaving a single unprotected hydroxyl group to be targeted in glycosylation reactions. These strategies entail exorbitant repeats of installation and removal of what is ultimately chemical waste-in addition to the extra solvent, energy, and time - making these approaches cost-inefficient and environmentally unfriendly.

As a result, strategies emerged to reduce the use of protecting groups and to regioselectively recognize a specific hydroxyl group. ${ }^{[6]}$ For instance, Griswold and Miller identified small peptides for potential regioselective acylation of partially protected carbohydrates ${ }^{[7]}$ while Kawabata and coworkers designed, chiral 4-pyrrolidinopyridine derivatives ${ }^{[8]}$ and DMAPcontaining small peptides ${ }^{[8-9]}$ for regioselective functionalization of monosccharide and even applied one of them to the regioselective monoacetylation of natural product derivatives. ${ }^{[9 \mathrm{~d}, 10]}$ 
The Aoyama group used arylboronates for the regiospecific alkylation ${ }^{[11]}$ and the glycosylation ${ }^{[12]}$ of monosaccharides with a focus on fucosides. Taylor used borinic acids as catalysts for regioselective functionalization of monosaccharidescis-diols. ${ }^{[13]}$ Transition metals have also been exploited for regioselective transformations of carbohydrates. Most notably, organotin derivatives (e.g. $\mathrm{Bu}_{2} \mathrm{SnO}, \mathrm{Oct}_{2} \mathrm{SnCl}_{2}{ }^{[14]}$ ) have found numerous applications and research is still ongoing today, despite of the toxicity associated with organic tin derivatives. ${ }^{[15]}$ For regioselective functionalization on monosaccharides, other transition metals has been used, such as copper ${ }^{[16]}$ and iron ${ }^{[17]}$, as well as other additives as reviewed recently. ${ }^{[18]}$ Most of these approaches have been successfully applied to carbohydrates featuring cis-diols (fucose, galactose, mannose), but rarely provide good regioselectivities for glucose-having only equatorial hydroxyl groups. An example of such a method has been reported by Onomura and co-workers although using potentially toxic organotin catalysts. ${ }^{[14 b]}$ A highly regioselective synthesis plan that is rich in atom economy, is green and is applicable to glucose is an unmet need.

We have previously developed directing-protecting groups (DPGs) which induced regioselective functionalization and glycosylation (Figure 1) of glucopyranosides. ${ }^{[19]}$ This approach relied on the use of a single protecting group, installed on the primary hydroxyl at position 6, which interacted with the secondary unprotected hydroxyl groups. Unfortunately, removal of these DPGs, similarly to most commonly used protecting groups, yielded an inert protecting fragment that would require further chemical transformations to be recycled into a useable chemical. Regrettably, while some protecting groups (e.g., benzylidene) can be hydrolyzed (e.g., into benzaldehyde), easily recycled and reused, they are hardly useable to regioselectively functionalize positions 2 or 3 .

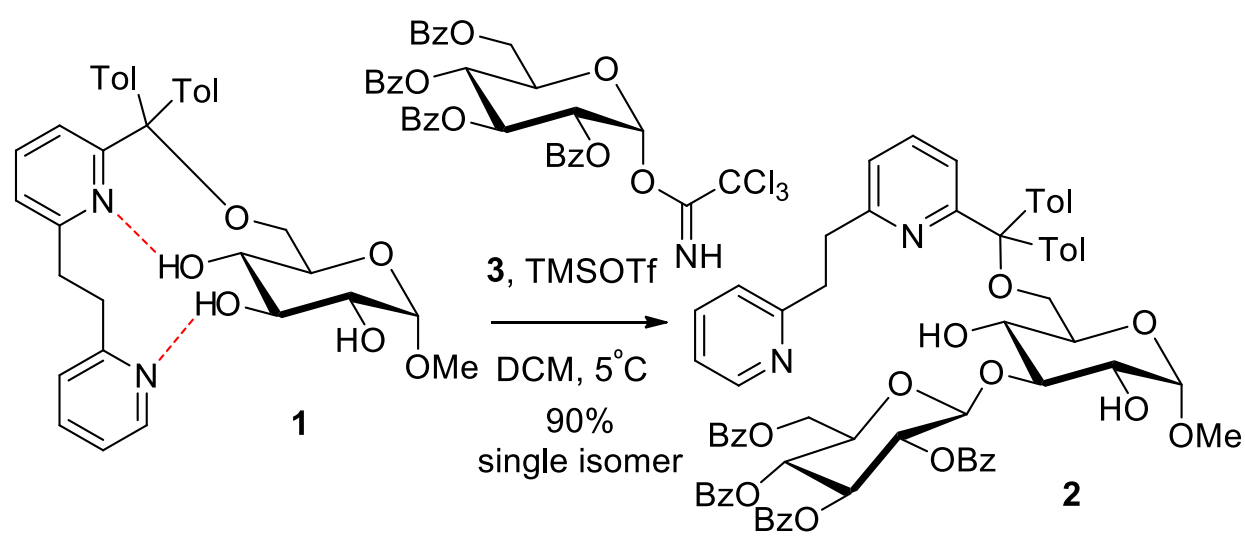

Figure 1. Previously reported DPG-induced regioselective glycosylation. ${ }^{[19]}$

\section{Results and Discussion}


Methodology. We planned to address regioselectivity and, in parallel, preclude any protection/deprotection steps. We opted for boronic esters due to their promising, labile covalent bonds (Figure 2). ${ }^{[20]}$ This strategy is in line with the green chemistry principles formulated by Anastas and Warner. ${ }^{[21]}$ Hydrolysis of such a protecting group would regenerate the boronic acid to be recycled and reused with no further transformation (atom economy, reduction of derivatives and somewhat catalysis).

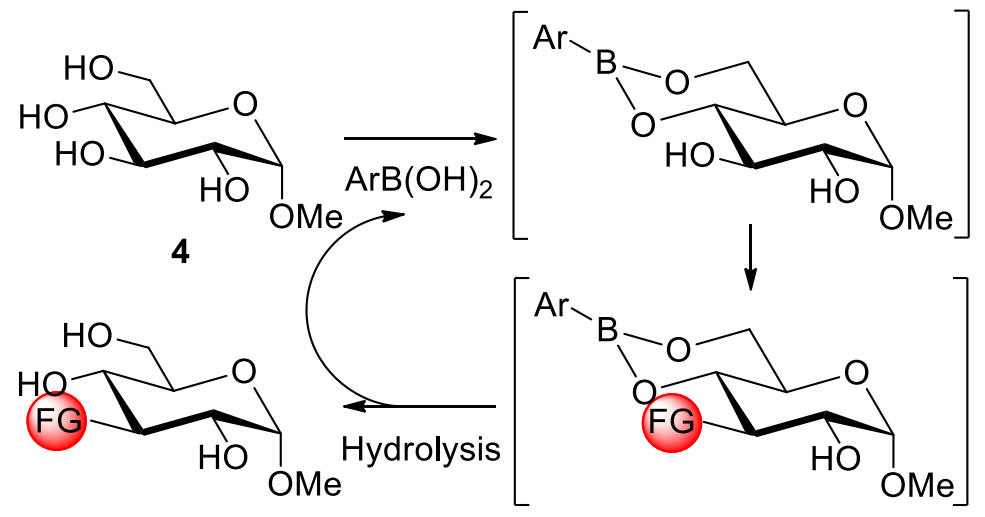

Figure 2. Proposed strategy using arylboronic acids as transient directing-protecting groups. $\mathrm{FG}=\mathrm{Ac}, \mathrm{Bz}$, Piv.

Although the use of arylboronic acids as protecting groups was proposed more than 50 years ago, ${ }^{[22]}$ their full potential in regioselective functionalization of carbohydrates has never been explored. It is not until recently that they were used in glycosylation reactions. However, the yield or the regioselectivity with glucopyranosides as the acceptor was low (35-63\%, 1:2.57.3) or unmentioned. ${ }^{[23]}$ Herein, we planned to exploit boronic acids as the only protecting groups-leaving positions 2 and 3 free to react (Figure 2)-hence fully exploiting the potential of arylboronic acids as transient directing-protecting groups (TDPGs).

Selection of boronic acids. We first considered a diverse set of commercially available boronic acids (Figure 3). We tested the stability of the corresponding boronate esters, evaluated their ability to induce regioselective acylation, optimized the reaction conditions, and then applied the most promising ones on a 1-gram and 10-gram scale to assess their applicability. Preliminary studies in deuterated solvents with boronic acids 6a-c showed that these boronic esters could be hydrolyzed in $\mathrm{D}_{2} \mathrm{O}$. It also quickly appeared that acidic conditions (i.e., silica gel) also led to significant hydrolysis of the boronic ester and indicated that traces of water may be detrimental to our strategy. 


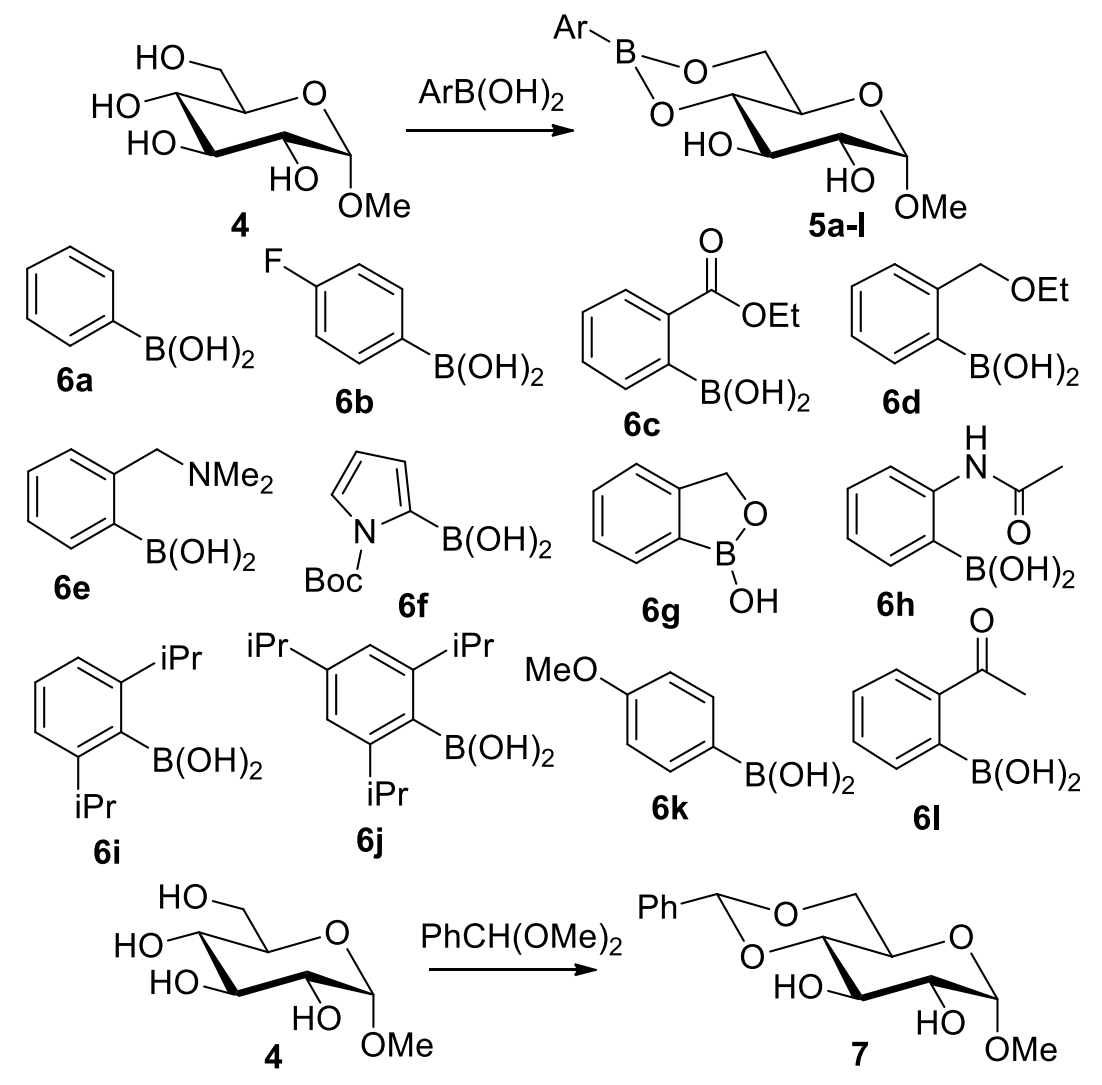

Figure 3. Arylboronic acids tested as transient directing-protecting groups (TDPGs) and carbon-containing analog 6.

Regioselective acylation. We have previously exploited the intramolecular hydrogen bond network to modulate the relative reactivity of secondary hydroxyl groups $\mathrm{OH}-2$ and $\mathrm{OH}-3 .{ }^{[19]}$ The electronic and structural properties of the boronate derivatives $4 \mathrm{a}-\mathrm{l}$ are expected to affect the network with $\mathrm{OH}-2$ and $\mathrm{OH}-3$. To test this hypothesis, we used these boronic acids in onepot acylation reactions. We optimized the conditions to insert, react, and remove the TDPGs in a single experiment. Among these optimizations were the electrophile addition time, the amounts of electrophile and catalyst, the chemical nature of the electrophile, the solvent, the concentration of glucopyranoside, and the reaction time (supporting information). We observed that the optimal amount of DMAP was in the 10-25 mol\% range, excess of $\mathrm{Ac}_{2} \mathrm{O}$ led to increased amount of overreacted product, and $\mathrm{PivCl}$, a larger reagent, did not produce a significant amount of doubly reacted products. 
Table 1. Functionalizing methyl- $\alpha$-D-glucopyranoside $4^{\text {a }}$
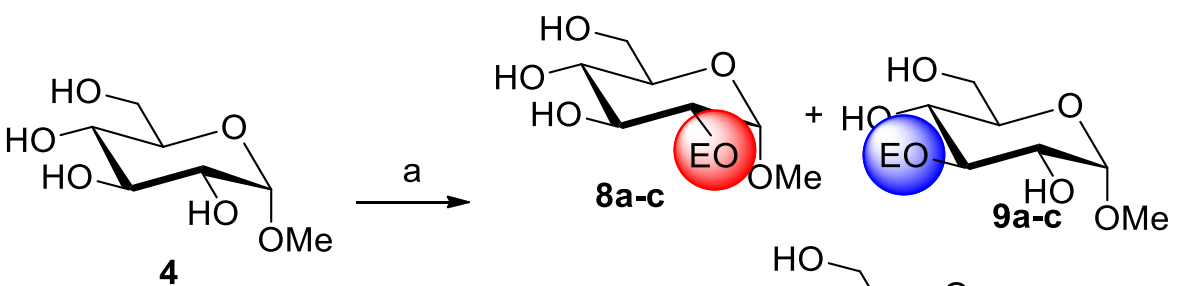
a: $E=A c$
b: $\mathrm{E}=\mathrm{Bz}$
c: $E=P i v$

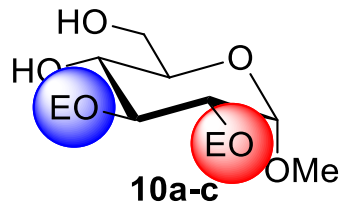

\begin{tabular}{|c|c|c|c|c|}
\hline Entry & TDPG & Electrophile $^{\mathrm{a}}$ & Yield $^{\mathrm{b}}$ & $7: 8: 9$ \\
\hline 1 & $-^{\mathrm{c}}$ & $\mathrm{Ac}_{2} \mathrm{O}$ & $87 \%$ & $29: 64: 7^{\mathrm{d}}$ \\
\hline 2 & \multirow{5}{*}{$6 a$} & $\mathrm{Ac}_{2} \mathrm{O}$ & $80 \%$ & $37: 54: 9$ \\
\hline 3 & & $\mathrm{BzCl}^{\mathrm{e}}$ & $87 \%$ & $83: 4: 13$ \\
\hline 4 & & $\mathrm{BzCl}$ & $82 \%$ & $79: 10: 11$ \\
\hline 5 & & $\mathrm{PivCl}$ & $95 \%$ & $83: 10: 7^{\mathrm{d}}$ \\
\hline 6 & & $\mathrm{PivCl}^{\mathrm{e}}$ & $94 \%$ & $92: 7: 1^{\mathrm{d}}$ \\
\hline 7 & \multirow{3}{*}{$6 b$} & $\mathrm{Ac}_{2} \mathrm{O}$ & $81 \%$ & $35: 49: 16^{\mathrm{f}}$ \\
\hline 8 & & $\mathrm{BzCl}$ & $82 \%$ & $75: 12: 13$ \\
\hline 9 & & $\mathrm{PivCl}$ & $79 \%$ & $86: 13: 1^{\mathrm{f}}$ \\
\hline 10 & \multirow{3}{*}{$6 c$} & $\mathrm{Ac}_{2} \mathrm{O}$ & $80 \%$ & $18: 66: 16^{\mathrm{d}}$ \\
\hline 11 & & $\mathrm{BzCl}$ & $51 \%$ & $33: 53: 14^{\mathrm{f}}$ \\
\hline 12 & & $\mathrm{PivCl}$ & $73 \%$ & $63: 36: 1^{\mathrm{e}}$ \\
\hline 13 & \multirow{2}{*}{$6 \mathrm{~d}$} & $\mathrm{Ac}_{2} \mathrm{O}$ & $82 \%$ & $26: 55: 19$ \\
\hline 14 & & $\mathrm{PivCl}$ & $91 \%$ & $82: 15: 3$ \\
\hline 15 & \multirow{3}{*}{$6 e$} & $\mathrm{Ac}_{2} \mathrm{O}$ & $\mathrm{n} / \mathrm{d}^{\mathrm{g}}$ & - \\
\hline & & & & \\
\hline 16 & & $\mathrm{PivCl}$ & $86 \%$ & $60: 24: 16$ \\
\hline 17 & $6 f$ & $\mathrm{Ac}_{2} \mathrm{O}$ & $\mathrm{n} / \mathrm{d}^{\mathrm{g}}$ & - \\
\hline
\end{tabular}




\begin{tabular}{|c|c|c|c|c|}
\hline 19 & \multirow[b]{2}{*}{$6 g$} & $\mathrm{Ac}_{2} \mathrm{O}$ & $\mathrm{n} / \mathrm{d}^{\mathrm{g}}$ & - \\
\hline 20 & & $\mathrm{PivCl}$ & $86 \%$ & $37: 58: 5^{\mathrm{f}}$ \\
\hline 21 & \multirow[b]{2}{*}{$6 \mathrm{~h}$} & $\mathrm{Ac}_{2} \mathrm{O}$ & $\mathrm{n} / \mathrm{d}^{\mathrm{g}}$ & - \\
\hline 22 & & $\mathrm{PivCl}$ & $71 \%$ & $30: 17: 51$ \\
\hline 23 & \multirow{3}{*}{$6 \mathrm{k}$} & $\mathrm{Ac}_{2} \mathrm{O}$ & $57 \%$ & $52: 45: 3^{f}$ \\
\hline 24 & & $\mathrm{BzCl}$ & $73 \%$ & $78: 12: 10$ \\
\hline 25 & & $\mathrm{PivCl}$ & $42 \%$ & $74: 13: 13^{f}$ \\
\hline 26 & \multirow{3}{*}{61} & $\mathrm{Ac}_{2} \mathrm{O}$ & $56 \%$ & $34: 34: 32^{\mathrm{d}}$ \\
\hline 27 & & $\mathrm{BzCl}$ & $66 \%$ & $52: 22: 26$ \\
\hline 28 & & $\mathrm{PivCl}$ & $82 \%$ & $66: 18: 16$ \\
\hline
\end{tabular}

${ }^{a} \alpha$-GlcOMe 4, toluene, Dean-Stark, 1 h, then $\operatorname{ArB}(\mathrm{OH})_{2} 1.10$ eq., toluene, Dean-Stark, 1

h, then $\mathrm{K}_{2} \mathrm{CO}_{3} 10.0$ eq., DMAP 20 mol\% then acylating agent 1.05 eq. r.t., 2-16 h, 50-

$100 \mathrm{mg}$ scale. ${ }^{\mathrm{b}} \mathrm{NMR}$ yields. ${ }^{\mathrm{c}}$ Reaction carried out with 4,6- $O$-benzylidene methyl- $\alpha-\mathrm{D}-$

glucopyranoside 7 . ${ }^{\mathrm{d}}$ Median value of triplicates; yield and ratio are $\pm<5 \%$ in most cases.

${ }^{\mathrm{e}}$ DMAP $50 \mathrm{~mol} \%$. ${ }^{\mathrm{f}}$ Lowest value of duplicates. ${ }^{\mathrm{g}}$ Complex mixture.

We applied the optimized conditions to the regioselective functionalization of methyl $\alpha$-Dglucopyranoside after coupling with our set of boronic acids (Table 1). Successfully, we were able to monoacylate methyl $\alpha$-D-glucopyranoside in a one-pot procedure at positions 2 and 3 exclusively with no detectable amount of the 4 and 6-O-acetylated isomers. Additionally, we achieved similar overall conversion to that observed using 7 (entry 1 vs. entry 2), however in a one-pot fashion - shortening the synthetic sequence by 2 steps. This data demonstrated that the introduction of the TDPG was complete and that the stability of the boronate enabled acylation without significant hydrolysis of the boronic ester. It is noteworthy that the highest conversion was observed only when in situ pre-dried methyl $\alpha$-D-glucopyranoside was used. From our observations, traces of water were extremely detrimental, likely affecting the stability of the boronic esters and/or reacting with the acylating agents. This prompted the use of toluene and a Dean-Stark apparatus.

Boronic acid $\mathbf{6 a}$ favored reaction at position 2 more than was $\mathbf{6 c}$ (Table 1, acetylation: entries 2 vs. 10; benzoylation: entries 4 vs 11; pivalation: entries 5 vs. 12). Additionally, a 
small electrophile $\left(\mathrm{Ac}_{2} \mathrm{O}\right)$ reacted preferentially at position 3 while larger ones $(\mathrm{PivCl}$ and $\mathrm{BzCl}$ ) reacted primarily at position 2. As a result, 6a with $\mathrm{Ac}_{2} \mathrm{O}$ and $\mathbf{6 c}$ with $\mathrm{PivCl}$ had synergistic effects (Table 1, entry 2 and entry 12). The ester of $\mathbf{6 c}$ is coordinating with the boron atom and may induce electronic effects responsible for the observed selectivity. With 6d-6h, a group adjacent to the boronic acid will coordinate to the boron atom. The regioselectivities observed with the five boronic acids filled a spectrum between those obtained with $\mathbf{6 a}$ and $\mathbf{6 c} ; \mathbf{6 d}$ provided a selectivity of 2.4:1 for acetylation at position 3 and 5.7:1 for pivalation at position 2. We evaluated the effect of bulky groups but observed minimal acylation conversion $(\mathbf{6 i}, \mathbf{6 j}$, data not shown) or complex mixtures. Conversely, with the cyclic monoester $\mathbf{6 g}$ we observed inverse regioselectivity for the pivalation. Surprisingly, the yield of acetylation was often lower than pivalation as shown with (6d-l).

Structural information. We obtained crystal structures of $4 \mathrm{a}$ and $4 \mathrm{~b}$ to confirm the functionalization, however these structures were not representative of the hydrogen bonding in. These structures showed that the $\mathrm{OH}-2$ is interacting with $\mathrm{O}-1$, while $\mathrm{OH}-3$ does not interact with either O-2 or O-4 but interacts with neighboring carbohydrates in the crystal (Figure 4). The crystalline state is therefore not informative on the solution conformations and hydrogen bond network.
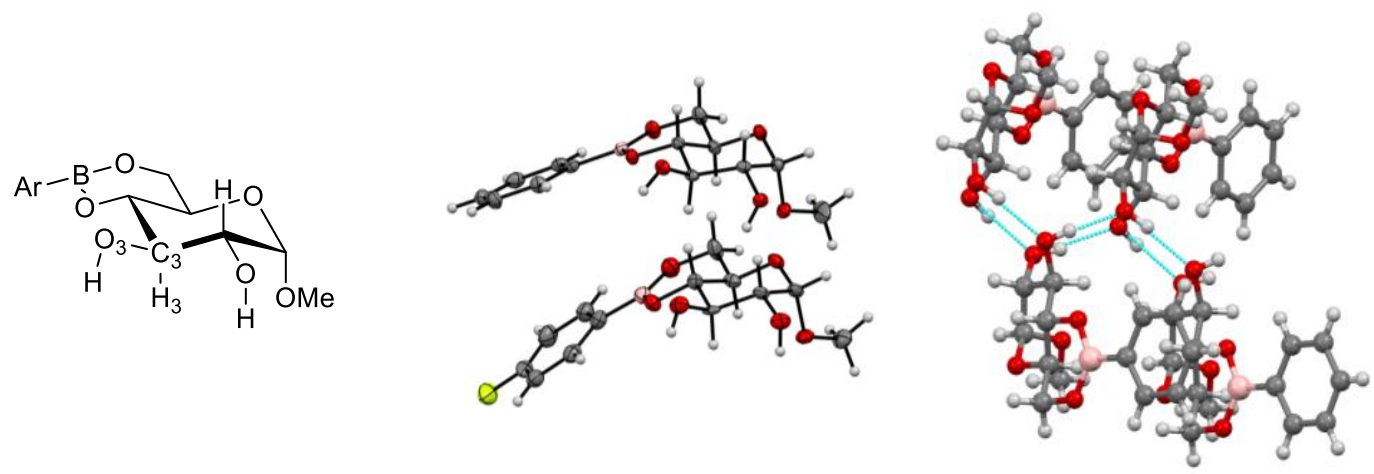

Figure 4. ORTEP representations of molecular structures of $\mathbf{5 a}$ and $\mathbf{5 b}$ determined by X-ray diffraction. Crystal structure of $\mathbf{5 a}$, dashed lines represent hydrogen bonds. Ellipsoids shown at $50 \%$ probability level.

We then turned our attention to NMR spectroscopy which was instrumental in determining the hydrogen bond network in our previous work. ${ }^{[19 a]}$ Interestingly, the ${ }^{1} \mathrm{H}$ NMR spectrum of 5c ester in deuterated DCM showed two signals, one at 2.87 (singlet) and one at $2.37 \mathrm{ppm}$ (doublet) corresponding to OH-2 and OH-3 (Figure 5). Previous work has shown that the multiplicity of these signals are indicative of intramolecular hydrogen bonds. ${ }^{[19 a]}$ The doublet with a coupling constant of $9.5 \mathrm{~Hz}$ revealed a torsional angle from $\mathrm{H}-\mathrm{C} 2-\mathrm{O} 2-\mathrm{H}-2$ of ca. $150^{\circ}$ 
which would result from a hydrogen bond between $\mathrm{OH}-2$ and OMe already observed in other similar glucopyranoside derivatives. ${ }^{[19 b]}$ In contrast, the singlet corresponding to $\mathrm{OH}-3$ indicated a $\mathrm{H} 3-\mathrm{C} 3-\mathrm{O} 3-\mathrm{H}$ torsional angle of ca. $90^{\circ}$ consequent of a hydrogen bond with either O-4 or O-2.

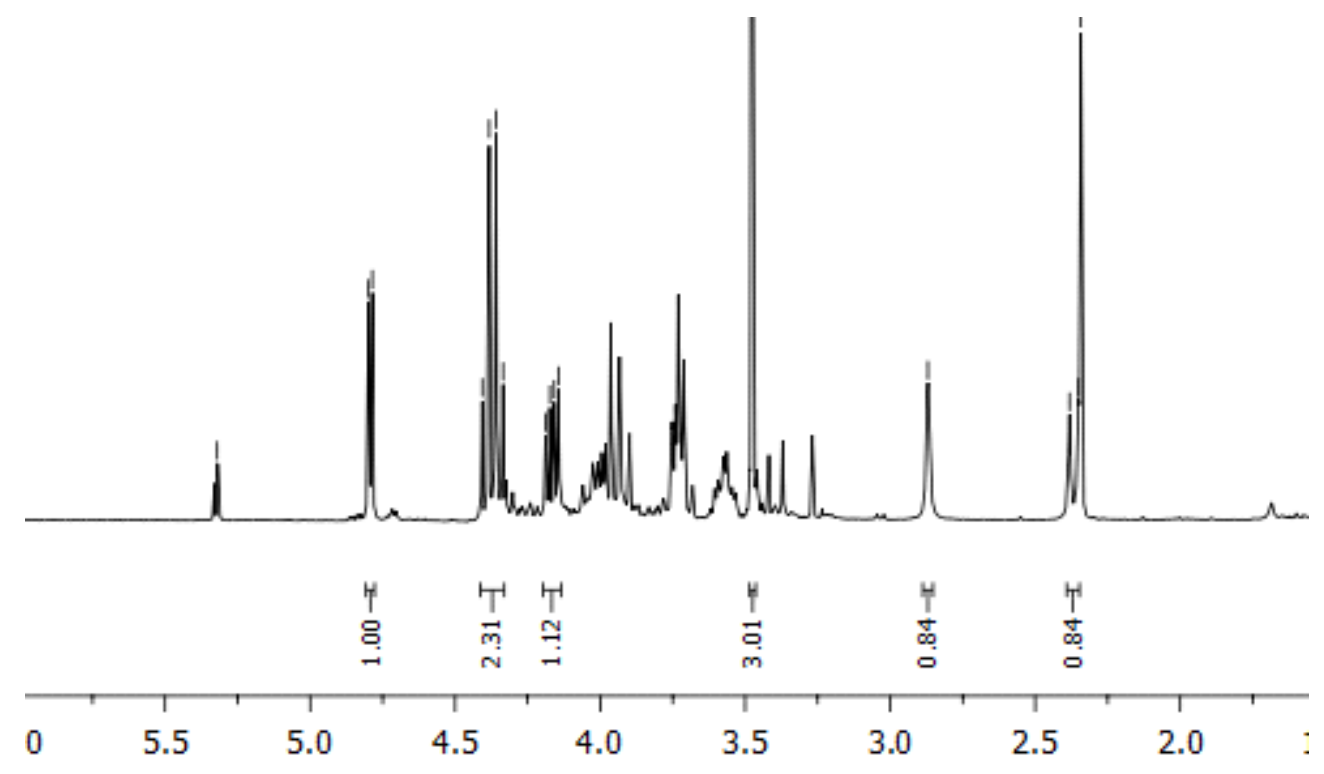

Figure 5. ${ }^{1} \mathrm{H}$ NMR of a crude mixture of 5a showing the two hydroxyl groups as a singlet (2.97 ppm) and a doublet (2.36 ppm).

The experimental data agreed with molecular modeling (DFT), which suggested a slight preference for OH-3 hydrogen bonded with O-4 over O-2 in 5c. The ester carbonyl oxygen complexed with the boron atom, activating the O-4 and inducing a stronger hydrogen bond between OH-3 and O-4 (Figure S3). The lowest-in-energy conformation was established for 5a, 5c, and the benzylidene analog 7 for comparison. Upon rotating the $\mathrm{C}-\mathrm{O} 3$ bond, the hydrogen bond preference in $\mathbf{5 c}$ was demonstrated by the minimum energy at torsion angle ca. $50^{\circ}$ (interaction with O-4) and a difference of $0.65 \mathrm{kcal} / \mathrm{mol}$ at torsion angle ca. $190^{\circ}$ (interaction with O-2). Contrastingly, 7 exhibited a flip in the minima (negligible energy difference) and 5a had energy profile similar to 7 (Figure 6). The slight energetic preference of 5c would explain the improved regioselectivity - the energy difference between a ratio of 1.3:1 (with 5a) and a ratio of 9:1 (with $\mathbf{5 c}$ ) being ca. $1 \mathrm{kcal} / \mathrm{mol}$. Although the differences are small between the three energy profiles, computed relative energies between similar compounds containing only boron, oxygen, carbon and hydrogens are usually accurate. 


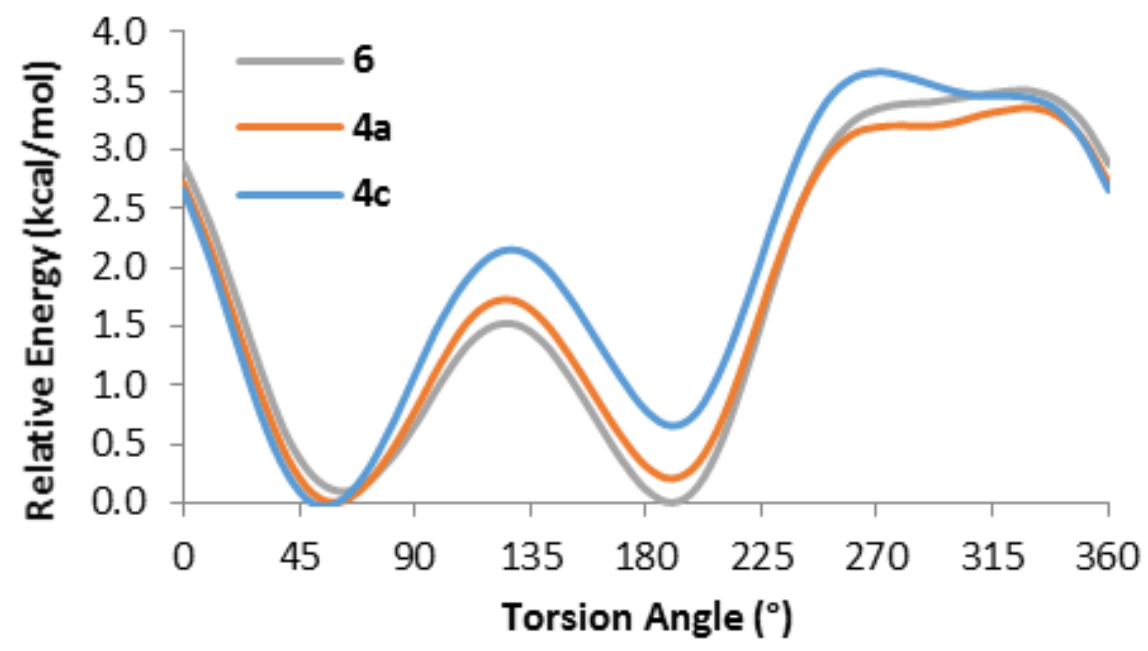

Figure 6. Energy profiles when rotating $\mathrm{C}-\mathrm{O} 3$ bond with three different 4,6-O-protected methyl $\alpha$-D-glucopyranoside.

The computations revealed that the ester carbonyl oxygen complexed with the boron atom, activating the O-4 and inducing a stronger hydrogen bond between OH-3 and O-4 (Figure 7).
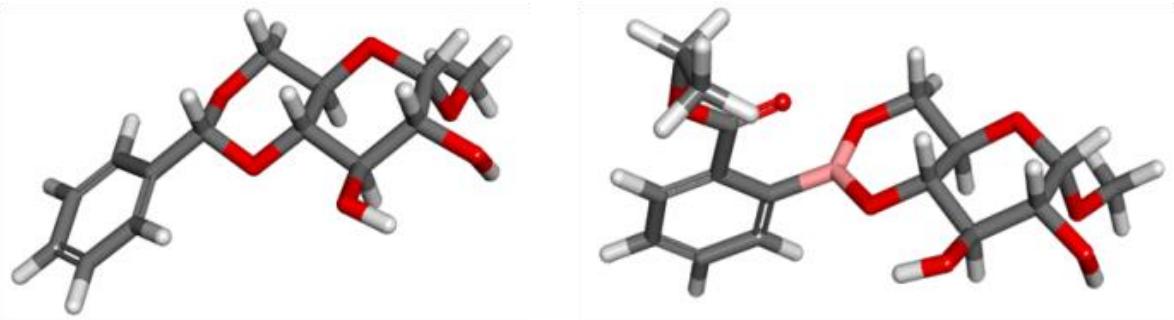

Figure 7. Minimum energy conformations of $\mathbf{7}$ (left) and 5c (right) derived from methyl 4,6$O$ - $\alpha$-D-glucopyranoside, indicating the different preferred hydrogen bonding networks.

Application. The applicability and reproducibility of this methodology was demonstrated on a larger scale ( $c a .1 \mathrm{~g}$ ), although the measured yields decreased for the pivalation and benzoylation (Table 2). Boronic acids $\mathbf{6 c}$ and $\mathbf{6 a}$ maintained regioselective acetylation and pivalation of our test substrate with regioselectivity significantly higher than with the more commonly used substrate 7 .

Ultimately, the optimized conditions led to excellent conversion and good regioselectivity for the acetylation at position 3 (ca. 2.5:1) and pivalation at position 2 (12:1) starting from fully unprotected methyl- $\alpha$-D-glucopyranoside. Interestingly, when excess of electrophile was used, the pivalation is quantitative with little dipivaloylated products.

Our main objective is to functionalize glucose derivatives such as a-GlcOMe 4, regioselectively, as the presence of cis-diols in other monosaccharides enables the use of 
several other methods. However, considering the high degree of selectivity of the acylation reactions, the two most effective boronic acids $\mathbf{6 a}$ and $\mathbf{6 c}$ were tested on different substrates: $\beta$-GlcOOct 11, $\alpha$-GalOMe 12 and $\alpha$-ManOMe 13 (Table 2, Entries 13-18) for acetylation and pivalation on a $1 \mathrm{~g}$ scale. Interestingly, acetylation of $\beta$-GlcOOct 11 (Table 2, Entry 10) and pivalation of $\alpha$-GalOMe 12 (Table 2, Entry 16) showed selectivity at position 2 and 3 respectively in presence of $\mathrm{B}(\mathrm{OH})_{2} \mathrm{PhCOOEt}$. The absence of intramolecular hydrogen bond between O-2 and the anomeric position of the $\beta$-GlcOOct 11, is likely the cause of the drop and reversal of selectivity when moving from $\alpha$-GlcOMe (Table 2, Entry 4 ) to $\beta$-GlcOOct (Table 2, Entry 10). In the case of the $\alpha$-GalOMe 12, the shape of the 4,6-O-boronate intermediate is very different from the one derived from $\alpha$-GlcOMe 4, allowing an extra hydrogen bonding between the ethyl ester and O-3. 
Table 2. Large scale functionalization. $1.0-10.0 \mathrm{~g}$ scale.

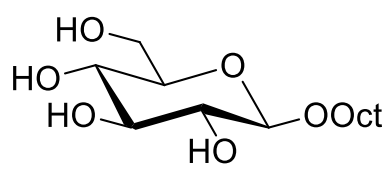

11

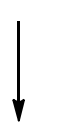

2-O-acyl 14

3-O-acyl 15

2,3-di-O-acyl 16

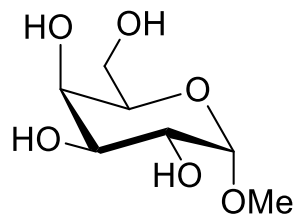

12

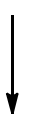

2-O-acyl 17

3-O-acyl 18

2,3-di-O-acyl 19

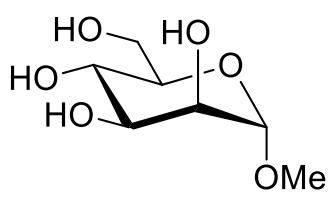

13

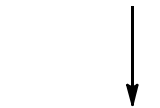

2-O-acyl 20

3-O-acyl 21

2,3-di-O-acyl 22

a: Acetate; b: Pivalate

\begin{tabular}{|c|c|c|c|c|c|}
\hline Entry & Substrate & TDPG & Electrophile $^{\mathrm{a}}$ & NMR Yield $^{b}$ & Regioselectivity $^{c}$ \\
\hline 1 & 7 & $-d$ & $\mathrm{Ac}_{2} \mathrm{O}$ & $66 \%$ & $34: 46: 20$ \\
\hline 2 & 7 & $-d$ & $\mathrm{BzCl}$ & $73 \%$ & $59: 23: 18$ \\
\hline 3 & 7 & $-d$ & $\mathrm{PivCl}$ & $83 \%$ & $83: 11: 6$ \\
\hline 4 & 4 & $6 c$ & $\mathrm{Ac}_{2} \mathrm{O}$ & $80 \%{ }^{\mathrm{e}}$ & $28: 71: 1$ \\
\hline 5 & 4 & $6 \mathbf{a}$ & $\mathrm{BzCl}$ & $61 \%{ }^{\mathrm{e}}$ & $90: 9: 1$ \\
\hline 6 & 4 & $6 \mathbf{a}$ & $\mathrm{PivCl}$ & $70 \%{ }^{\mathrm{e}}$ & $93: 7: \mathrm{n} / \mathrm{d}$ \\
\hline 7 & 4 & $6 \mathbf{a}$ & $\mathrm{PivCl}^{\mathrm{f}}$ & $>95 \%$ & $92: 3: 5$ \\
\hline 8 & 4 & $6 \mathbf{a}$ & $\mathrm{PivCl}^{\mathrm{e}, \mathrm{g}}$ & $86 \%$ & $92: 7: 3$ \\
\hline 9 & 4 & $6 \mathbf{a}$ & $\mathrm{PivCl}^{\mathrm{e}, \mathrm{h}}$ & $87 \%$ & $86: 7: 7$ \\
\hline 10 & 11 & $6 c$ & $\mathrm{Ac}_{2} \mathrm{O}$ & $92 \%$ & $62: 32: 6$ \\
\hline 11 & 12 & $6 \mathbf{a}$ & $\mathrm{Ac}_{2} \mathrm{O}$ & $64 \%$ & $17: 55: 28$ \\
\hline 12 & 12 & $6 c$ & $\mathrm{Ac}_{2} \mathrm{O}$ & $64 \%$ & $31: 11: 58$ \\
\hline 13 & 11 & $6 \mathbf{a}$ & $\mathrm{PivCl}$ & $55 \%$ & $22: 40: 38$ \\
\hline 14 & 11 & $6 c$ & $\mathrm{PivCl}$ & $54 \%$ & $0: 50: 50$ \\
\hline 15 & 12 & $6 \mathbf{a}$ & $\mathrm{PivCl}$ & $66 \%$ & $22: 34: 44$ \\
\hline 16 & 12 & $6 c$ & $\mathrm{PivCl}$ & $72 \%$ & $19: 76: 5$ \\
\hline 17 & 13 & $6 \mathbf{a}$ & $\mathrm{PivCl}$ & $27 \%$ & $100: \mathrm{n} / \mathrm{d}: \mathrm{n} / \mathrm{d}$ \\
\hline 18 & 13 & $6 c$ & $\mathrm{PivCl}$ & $19 \%$ & $100: \mathrm{n} / \mathrm{d}: \mathrm{n} / \mathrm{d}$ \\
\hline
\end{tabular}

${ }^{\mathrm{a}}$ Optimal conditions: dry $\alpha$-GlcOMe 4, toluene, Dean-Stark, 1 h, then $\mathrm{B}(\mathrm{OH})_{2}$ PhCOOEt 1.10 eq., toluene, Dean-Stark, 1 h, then $\mathrm{K}_{2} \mathrm{CO}_{3} 10.0$ eq., $\mathrm{Ac}_{2} \mathrm{O} / \mathrm{BzCl} / \mathrm{PivCl} 1.05$ eq., $1 \mathrm{~h}$, then 


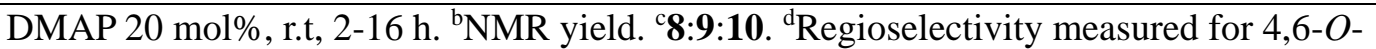
benzylidene methyl- $\alpha$-D-glucopyranoside 7. ${ }^{\mathrm{e}}$ Median value of triplicates; yield and ratio are $\pm<5 \%$; ${ }^{\mathrm{f}}$ sing 5.0 eq. of $\mathrm{PivCl}$ and 0.8 eq. of DMAP. ${ }^{\mathrm{g}} 1 \mathrm{~g}$ scale, 60 mol\% DMAP.

Overall, we obtained four sets of reaction conditions with good regioselectivity: phenylboronic acid (6a) favors the formation of the 2-O-pivalate $\mathbf{8 b}$ (e.g. Table 2, Entry 7) while the use of $\mathrm{B}(\mathrm{OH})_{2} \mathrm{PhCOOEt}$ leads to the synthesis of three compounds, 3-O-acetate $\mathbf{8 c}$ (Table 2, Entry 4), 2-O-acetate 14a (Table 2, Entry 10) and 3-O-pivalate 18b (Table 2, Entry 16) with excellent yields and good to excellent regioselectivity.

The other conditions tested without monosaccharides 11-13 showed no or low regioselectivities.

A complete protocol. At the outset of this project, we planned to develop a green method that would convert an unprotected glucose derivative into a single regioisomer of the monofunctionalized derivative with optimal atom economy. The remaining obstacles in our strategy were isolating the major isomer and recovering the boronic acid. The optimal protocol shown in Figure 8 was devised after numerous iterations of reaction condition optimization, crystallization of the major product, and extraction of the boronic acid. Efforts were also made to reduce the amount of solvent (toluene) used throughout the process (ca. 0.1 $\mathrm{L}$ per $1 \mathrm{~g}$ of starting material).

Applied to $10 \mathrm{~g}$ of dry methyl- $\alpha$-D-glucopyranoside $\mathbf{4}$ in refluxing toluene, this protocol leads up to $6.9 \mathrm{~g}$ of crystallized 2- $O$-pivaloyl methyl- $\alpha$-D-glucopyranoside 8c after a single recrystallization while $6.2 \mathrm{~g}$ of the boronic acid was recovered on a silica gel pad.
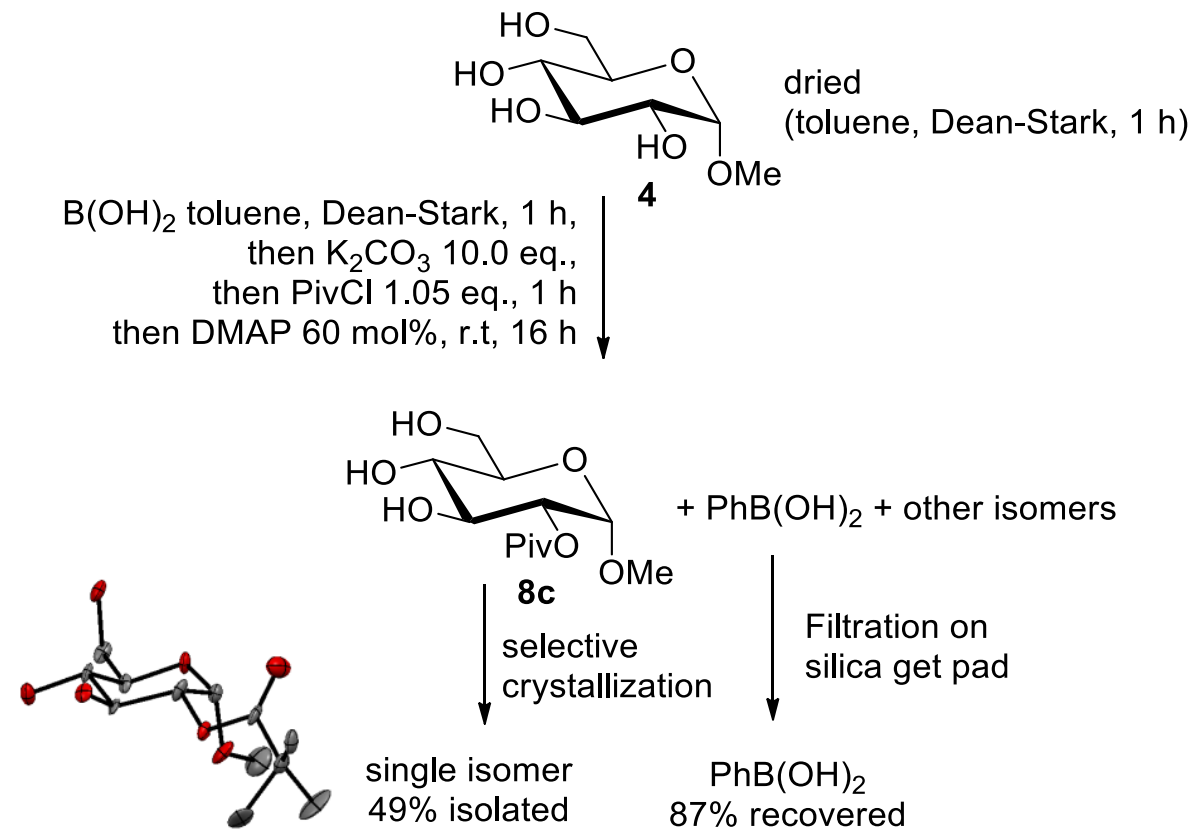
Figure 8. A single regioisomer (and recovered boronic acid) from unprotected methyl 4,6-O$\alpha$-D-glucopyranoside.

\section{Conclusions}

Our approach demonstrated that a judiciously selected boronic acid can be used to regioselectively functionalize simple unprotected carbohydrate units on small (50 to $100 \mathrm{mg}$ ) to medium scale (1-10 g) with good reproducibility if care is taken to ensure the dryness of the chemicals. More specifically, applied to $10 \mathrm{~g}$ of methyl- $\alpha$-D-glucopyranoside, this unique methodology enabled the functionalization of position 2 with excellent yields and regioselectivities with no need for time-consuming separation of regioisomers. This single one-pot procedure is significantly more economical than the use of protecting groups. The development of this new protocol paves the way to significantly more efficient and greener polysaccharide synthesis.

\section{Experimental Section}

General Information. All commercially available reagents were used without further purification unless otherwise stated. Optical rotations were measured on a JASCO DIP 140 in a $0.5 \mathrm{dm}$ cell at $22^{\circ} \mathrm{C}$ unless otherwise stated. FTIR spectra were recorded using a PerkinElmer Spectrum One FT-IR. ${ }^{1} \mathrm{H}$ and ${ }^{13} \mathrm{C}$ NMR spectra were recorded on Varian Mercury 400 $\mathrm{MHz}, 300 \mathrm{MHz}$, or Unity 500 spectrometers. Chemical shifts are reported in ppm using the residual of deuterated solvents as internal standard. Thin layer chromatography visualization was performed by UV or by development using $\mathrm{KMnO}_{4}, \mathrm{H}_{2} \mathrm{SO}_{4} / \mathrm{MeOH}$, Mo/Ce or curcumin solutions. Chromatography was performed on silica gel 60 (230-40 mesh). Low resolution mass spectrometry was performed by ESI using a Thermoquest Finnigan LCQ Duo. High resolution mass spectrometry was performed by EI peak matching $(70 \mathrm{eV})$ on a Kratos MS25 RFA double focusing mass spectrometer or by ESI on a Ion Spec 7.0 T FTMS at McGill University.

General procedure. A very detailed procedure is described below as several features are critical to avoid precipitation of the carbohydrate/boronic acid mixture and ensure optimal yields. In any case, a particular attention must be taken to reduce contact between the reagents/reaction mixture and water/moisture (i.e. when weighting or adding the reagents). Freshly purchased reagents (GlcOMe, $\mathrm{K}_{2} \mathrm{CO}_{3}, \mathrm{~B}(\mathrm{OH})_{2} \mathrm{COOEt}, \mathrm{B}(\mathrm{OH})_{2} \mathrm{Ph}, \mathrm{Ac} c_{2} \mathrm{O}, \mathrm{BzCl}$, PivCl, DMAP) are highly recommended. All of these reactions are carried out at reflux. Use extreme 
caution as the glassware may be hot. Ensure to cool down the reaction mixture prior to adding any chemicals to reduce the solvent vapors.

One-pot monoacetylation on a 1.0 g scale. Overnight oven-dried $\left(110{ }^{\circ} \mathrm{C}\right)$ methyl $\alpha$-Dglucopyranoside ( $1.00 \mathrm{~g}, 5.15 \mathrm{mmol}$ ) was weighted and added quickly (to minimize contact with air moisture from the air) to toluene $(1.0 \mathrm{~L})$ then suspended in toluene $(1 \mathrm{~L})$. This low concentration ( $c a .0 .005 \mathrm{M}, 1.0 \mathrm{~g}$ per L), 3 boiling chips and a large stirring bar are recommended to preclude precipitation. A copper wire/aluminum foil covered Dean-Stark apparatus $(20 \mathrm{~mL})$ was installed on top of the round bottom flask with a large water condenser and the system was placed under argon (large balloon of argon). The sidearm of the Dean-Stark apparatus was fully filled with toluene and the $2 \mathrm{~L}$ round bottom flask was covered with aluminum foil. The reaction mixture was heated to reflux using a heating mantle (it takes approximately $90 \mathrm{~min}$ to heat toluene up to the boiling point). After refluxing for $1 \mathrm{~h}$, solid 2-ethoxycarbonylphenylboronic acid (1.10 g, $5.67 \mathrm{mmol}, 1.10 \mathrm{eq}$.) was carefully added into the solution. After another $1 \mathrm{~h}$ of reflux, the reaction mixture was cooled down to $c a$. $40{ }^{\circ} \mathrm{C}$, capped with a rubber septum and a balloon of argon then cooled down to room temperature. Overnight oven-dried $\left(110{ }^{\circ} \mathrm{C}\right)$ solid $\mathrm{K}_{2} \mathrm{CO}_{3}(7.12 \mathrm{~g}, 10.0$ eq.) was added to the reaction mixture and suspended. Then neat $\mathrm{Ac}_{2} \mathrm{O}(511 \mu \mathrm{L}, 5.41 \mathrm{mmol}, 1.05$ eq. $)$ was added to the reaction flask, stir for $1 \mathrm{~h}$ at room temperature, then $4 \mathrm{~h}$ oven-dried $\left(110^{\circ} \mathrm{C}\right)$ recrystallized DMAP (126 mg, $1.03 \mathrm{mmol}, 0.20$ eq.) was added to the reaction flask. Stirring should be such that any material aggregated on the glassware surface is suspended. The reaction mixture was stirred for $2 \mathrm{~h}$ at room temperature under argon atmosphere then filtrated under vacuum through Büchner funnel to remove the excess of solid $\mathrm{K}_{2} \mathrm{CO}_{3}$. Toluene was evaporated under vacuum, and the ${ }^{1} \mathrm{H}$ NMR spectrum of the crude colorless syrup was taken in $\mathrm{MeOH}-\mathrm{d}^{4}$.

One-pot monobenzoylation on a $1.0 \mathrm{~g}$ scale. Following the procedure described above., methyl $\alpha$-D-glucopyranoside (1.00 g, $5.15 \mathrm{mmol}$ ), solid phenylboronic acid (691 mg, 5.67 mmol, 1.10 eq.), $\mathrm{K}_{2} \mathrm{CO}_{3}$ (7.12 g, 10.00 eq.), neat $\mathrm{BzCl}(628 \mu \mathrm{L}, 5.41 \mathrm{mmol}, 1.05$ eq.) and DMAP (126 mg, $1.03 \mathrm{mmol}, 0.20$ eq.) were reacted. However, the reaction was stirred for 16 $\mathrm{h}$ at room temperature (in I.2. the reaction mixture is stirred for $2 \mathrm{~h}$ ).

One-pot pivalation on a $1.0 \mathrm{~g}$ scale. Following the procedure described above., methyl $\alpha$-Dglucopyranoside (1.00 g, $5.15 \mathrm{mmol})$, solid phenylboronic acid (691 mg, $5.67 \mathrm{mmol}, 1.10 \mathrm{eq}$.), $\mathrm{K}_{2} \mathrm{CO}_{3}$ (7.12 g, 10.0 eq.), neat PivCl (666 $\mu \mathrm{L}, 5.41 \mathrm{mmol}, 1.05$ eq.) and DMAP (126 mg, 1.03 mmol, 0.20 eq.) were reacted. However, the reaction was stirred for $16 \mathrm{~h}$ at room temperature (in I.2. the reaction mixture is stirred for $2 \mathrm{~h}$ ). 
One-pot monoacetylation on a $50 \mathrm{mg}$ scale. Following the procedure described above., methyl $\alpha$-D-glucopyranoside $(50 \mathrm{mg}, 0.26 \mathrm{mmol})$ suspended in toluene $(50 \mathrm{~mL})$, solid 2ethoxycarbonylphenylboronic acid (55 mg, $0.28 \mathrm{mmol}, 1.10$ eq.), $\mathrm{K}_{2} \mathrm{CO}_{3}$ (356 mg, 10.0 eq.), a freshly prepared (in $5 \mathrm{~mL}$ flame-dried round-bottom flask) $0.50 \mathrm{M}$ solution (50 $\mu \mathrm{L}$ per $\mathrm{mL}$ ) of $\mathrm{Ac}_{2} \mathrm{O}$ (0.51 mL, $2.73 \mathrm{mmol}, 1.05$ eq.), DMAP (2.52 mL, $0.013 \mathrm{mmol}, 0.05$ eq.) were reacted.

One-pot monobenzoylation on a $50 \mathrm{mg}$ scale. Following the procedure described above., methyl $\alpha$-D-glucopyranoside (50 mg, $0.26 \mathrm{mmol}$ ) suspended in toluene $(50 \mathrm{~mL})$, solid phenylboronic acid (35 mg, $0.28 \mathrm{mmol}, 1.10$ eq.), $\mathrm{K}_{2} \mathrm{CO}_{3}$ (356 mg, 10.0 eq.), a freshly prepared (in $5 \mathrm{~mL}$ flame-dried round-bottom flask) $0.60 \mathrm{M}$ solution $(50 \mu \mathrm{L}$ per $\mathrm{mL}$ ) of $\mathrm{BzCl}$ (0.53 mL, $2.73 \mathrm{mmol}, 1.05$ eq.), DMAP ( $2.52 \mathrm{~mL}, 0.013 \mathrm{mmol}, 0.05$ eq.) were reacted.

One-pot pivalation on a $50 \mathrm{mg}$ scale. Following the procedure described in I.2., methyl $\alpha$-Dglucopyranoside (50 mg, $0.26 \mathrm{mmol}$ ) suspended in toluene $(50 \mathrm{~mL}$ ), solid phenylboronic acid (35 mg, $0.28 \mathrm{mmol}, 1.10$ eq.), $\mathrm{K}_{2} \mathrm{CO}_{3}$ (356 mg, 10.0 eq.), a freshly prepared (in $5 \mathrm{~mL}$ flamedried round-bottom flask) $0.50 \mathrm{M}$ solution $(60 \mu \mathrm{L}$ per $\mathrm{mL})$ of $\mathrm{PivCl}(0.56 \mathrm{~mL}, 2.73 \mathrm{mmol}$, 1.05 eq.), DMAP (2.52 mL, $0.013 \mathrm{mmol}, 0.05$ eq.) were reacted.

One-pot pivalation on a $1.0 \mathrm{~g}$ scale - purification. The crude toluene solution was filtered through a short silica gel pad $(30 \mathrm{~mL}$ of silica) then washed with a portion $(100 \mathrm{~mL})$ of $10 \%$ $\mathrm{MeOH} / \mathrm{EtOAc}$. The $\mathrm{MeOH} / \mathrm{EtOAc}$ mixture was evaporated under vacuum and the crude yellow oil was redissolved into EtOAc $(100 \mathrm{~mL})$. Then, the EtOAc crude solution was washed with portions of water $(9 \times 30 \mathrm{~mL})$. The water layer was evaporated under vacuum, redissolved into EtOAc $(100 \mathrm{~mL})$, dry with sodium sulfate, filtered, evaporated again under vacuum to collect the mixture of mono- and di- pivaloylated methylglucoside was collected as a white syrup (1054-1100 mg, 72-75\% crude yield). The white syrup was hen dissolved into a minimum amount of EtOAc $(\sim 10 \mathrm{~mL})$ and selectively crystallized overnight $(16 \mathrm{~h})$ into pentane $(100 \mathrm{~mL})$ to obtain pure methyl 2-O-pivaloyl- $\alpha$-D-glucopyranoside as white flaky crystals (686-703 mg, 47-48\% crystallized yield). The EtOAc layer from the aqueous extraction was evaporated under vacuum and the phenylboronic acid was collected as a white solid (494-519 mg, 75-79\% recovery). Both water and EtOAc layers were monitored by TLC (50\% EtOAc/Hex).

One-pot pivalation on a 10.0 g scale - purification. The crude toluene solution was filtered through a short silica gel pad $(300 \mathrm{~mL}$ of silica) then washed with a portion $(1 \mathrm{~L})$ of $10 \%$ $\mathrm{MeOH} / \mathrm{EtOAc}$. The $\mathrm{MeOH} / \mathrm{EtOAc}$ mixture was evaporated under vacuum and the crude yellow oil was redissolved into EtOAc $(1 \mathrm{~L})$. Then, the EtOAc crude solution was washed 
with portions of water $(9 \times 300 \mathrm{~mL})$. Only the first three washings $(3 \times 300 \mathrm{~mL})$ of the water layer were evaporated under vacuum (the rest was discarded), redissolved into EtOAc $(1 \mathrm{~L})$, dry with sodium sulfate, filtered, evaporated again under vacuum to collect the mixture of mono- and di- pivaloylated methylglucoside was collected as a white syrup $(9.0 \mathrm{~g}-9.3 \mathrm{~g}, 63$ $65 \%$ crude yield). The white syrup was hen dissolved into a minimum amount of EtOAc $(\sim 100 \mathrm{~mL})$ and selectively crystallized overnight $(16 \mathrm{~h})$ into pentane $(1 \mathrm{~L})$ to obtain pure methyl 2-O-pivaloyl- $\alpha$-D-glucopyranoside as white flaky crystals (6393-7376 mg, 45-51\% crystallized yield). The EtOAc layer from the aqueous extraction was evaporated under vacuum and the phenylboronic acid was collected as a white solid (6019-6260 mg, 86-90\% recovery). Both water and EtOAc layers were monitored by TLC (50\% EtOAc/Hex).

Methyl 4,6-phenylboronate- $\alpha$-D-glucopyranoside (5a). ${ }^{[2]}$ A suspension of methyl $\alpha$-Dglucopyranoside (501 mg, $2.58 \mathrm{mmol}$ ) in toluene $(25 \mathrm{~mL})$ was refluxed for $1 \mathrm{~h}$ using a DeanStark apparatus. Then phenylboronic acid (345 mg, $3.26 \mathrm{mmol}, 1.27$ eq.) was added and the reaction mixture was refluxed for $1 \mathrm{~h}$ using a Dean-Stark apparatus. The solution was cooled down to room temperature and the solvent evaporated under vacuum. The crude material was dissolved in DCM, filtrated and concentrated under vacuum. The remaining solid was dissolved in a minimum of boiling toluene and allowed to cool down to room temperature to obtain methyl 4,6-phenylboronate- $\alpha$-D-glucopyranoside 5a as small white needles crystals (683 mg, 95\% yield). $\mathrm{mp} 166-168{ }^{\circ} \mathrm{C}$ (toluene); $[\alpha]_{\mathrm{D}}{ }^{22}=+95.3^{\circ}\left(c 0.5, \mathrm{CHCl}_{3}\right.$ ); IR (film, $\mathrm{CHCl}_{3}$ ) v max: 3354, 2940, 2906, 1602, 1441, 1409, 1313, 1297, 1254, 1029, 909, $697 \mathrm{~cm}^{-1}$; ${ }^{1} \mathrm{H}$ NMR $\left(300 \mathrm{MHz}, \mathrm{CDCl}_{3}\right) \delta=7.47-7.35(\mathrm{~m}, 5 \mathrm{H}), 4.84(\mathrm{~d}, 1 \mathrm{H}, J=3.9 \mathrm{~Hz}), 4.25(\mathrm{dd}, 1 \mathrm{H}, J$ $=4.4,9.3 \mathrm{~Hz}), 3.97(\mathrm{t}, 1 \mathrm{H}, J=9.7 \mathrm{~Hz}), 3.93-3.65(\mathrm{~m}, 4 \mathrm{H}), 3.48(\mathrm{~s}, 3 \mathrm{H}) ;{ }^{13} \mathrm{C} \mathrm{NMR}(125 \mathrm{MHz}$, $\left.\mathrm{CDCl}_{3}\right) \delta=134.1$ (2C), 131.1 (2C), 127.6 (2C), 99.8, 74.8, 73.4, 72.5, 64.4, 64.3, 55.7; ${ }^{11} \mathrm{~B}$ $\operatorname{NMR}\left(160 \mathrm{MHz}, \mathrm{CDCl}_{3}\right) \delta=27.0$; HRMS (APCI+) calcd for $\left[\mathrm{C}_{13} \mathrm{H}_{17} \mathrm{BO}_{6}+\mathrm{H}\right]^{+}:$281.11964, found: 281.1188. HRMS (ESI-) calcd for $\left[\mathrm{C}_{13} \mathrm{H}_{17} \mathrm{BO}_{6}+\mathrm{CHO}_{2}\right]:$ : 325.10947, found: 325.11050. HRMS (ESI-) calcd for $\left[\mathrm{C}_{13} \mathrm{H}_{17} \mathrm{BO}_{6}+\mathrm{Cl}\right]^{-}: 315.08067$, found: 315.08200 .

Methyl 4,6-(para-fluoro)phenylboronate-a-D-glucopyranoside (5b). Following the procedure described in II.1, methyl $\alpha$-D-glucopyranoside (501 mg, $2.58 \mathrm{mmol}$ ) in toluene (25 $\mathrm{mL}$ ) and 4-fluorophenylboronic acid (398 mg, $3.84 \mathrm{mmol}, 1.10$ equiv.) afforded methyl 4,6(para-fluoro)phenylboronate- $\alpha$-D-glucopyranoside $\mathbf{5 b}$ as white fluffy cotton-like crystals (759 $\mathrm{mg}, 99 \%$ yield). $\mathrm{mp} 183-185^{\circ} \mathrm{C}$ (toluene); $[\alpha]_{\mathrm{D}}^{22}=+40.3^{\circ}\left(\right.$ c 1.0, $\mathrm{CHCl}_{3}$ ); IR (film, $\left.\mathrm{CHCl}_{3}\right) v$ $\max : 3353,2940,2910,1597,1510,1483,1405,1315,1298,1221,1085,1038,995,837,729$ $\mathrm{cm}^{-1} ;{ }^{1} \mathrm{H}$ NMR $\left(300 \mathrm{MHz}, \mathrm{CDCl}_{3}\right) \delta=7.82-6.99(\mathrm{~m}, 4 \mathrm{H}), 4.84(\mathrm{~d}, 1 \mathrm{H}, J=3.9 \mathrm{~Hz}), 4.24(\mathrm{dd}$, $1 \mathrm{H}, J=4.3 \mathrm{~Hz}, 9.3 \mathrm{~Hz}), 3.95(\mathrm{t}, 1 \mathrm{H}, J=10.2 \mathrm{~Hz}), 3.90-3.64(\mathrm{~m}, 4 \mathrm{H}), 3.48(\mathrm{~s}, 3 \mathrm{H}) ;{ }^{1} \mathrm{H}$ NMR $\left(300 \mathrm{MHz},\left(\mathrm{CD}_{3}\right)_{2} \mathrm{CO}\right) \delta=7.86-7.79(\mathrm{~m}, 2 \mathrm{H}), 7.12-7.06(\mathrm{~m}, 2 \mathrm{H}), 4.76(\mathrm{~d}, 1 \mathrm{H}, J=3.8 \mathrm{~Hz})$, 
$4.59(\mathrm{~d}, 1 \mathrm{H}, J=3.4 \mathrm{~Hz}), 4.20(\mathrm{dd}, 1 \mathrm{H}, J=4.7 \mathrm{~Hz}, 9.4 \mathrm{~Hz}), 3.96(\mathrm{t}, 1 \mathrm{H}, J=9.9 \mathrm{~Hz}), 3.91-3.68$ (m 4H), 3.41 (s, 3H); ${ }^{13} \mathrm{C}$ NMR $\left(125 \mathrm{MHz},\left(\mathrm{CD}_{3}\right)_{2} \mathrm{CO}\right) \delta=167.2,163.9,137.3,137.2,115.2$, $114.9,101.5,76.4,73.6,73.3,65.2,65.1,55.5 ;{ }^{11} \mathrm{~B}$ NMR $\left(160 \mathrm{MHz}, \mathrm{CDCl}_{3}\right) \delta=31.7 ;{ }^{19} \mathrm{~F}$ NMR $\left(471 \mathrm{MHz}, \mathrm{CDCl}_{3}\right) \delta=-108.8$; HRMS (APCI+) calcd for $\left[\mathrm{C}_{13} \mathrm{H}_{16} \mathrm{BFO}_{6}+\mathrm{H}\right]^{+}: 299.1102$, found: 299.1100; HRMS (ESI-) calcd for $\left[\mathrm{C}_{13} \mathrm{H}_{16} \mathrm{BFO}_{6}+\mathrm{CHO}_{2}\right]: 343.10005$, found: 343.10100 .

Methyl 4,6-(ortho-ethoxycarbonyl)phenylboronate- $\alpha$-D-glucopyranoside (5c). Following the procedure described in II.1, methyl $\alpha$-D-glucopyranoside (246 mg, $1.27 \mathrm{mmol}$ ) in toluene $(13 \mathrm{~mL})$ and 2-ethoxycarbonylphenylboronic acid (221 mg, $1.14 \mathrm{mmol}, 0.90$ equiv.) afforded methyl 4,6-(ortho-ethoxycarbonyl)phenylboronate- $\alpha$-D-glucopyranoside $\mathbf{5 c}$ as white foam crystals $\left(406 \mathrm{mg}, 91 \%\right.$ yield). $[\alpha]_{\mathrm{D}}^{22}=+67.3^{\circ}\left(c 0.7, \mathrm{MeOH}\right.$ ); IR (film, $\left.\mathrm{CHCl}_{3}\right) \vee \max$ : 3355, 2913, 1680, 1396, 1366, 1262, 1285, 1186, 1111, 1024, $899843,754,710,670 \mathrm{~cm}^{-1} ;{ }^{1} \mathrm{H}$ NMR (300 MHz, CD $\left.{ }_{3} \mathrm{OD}\right) \delta=8.02-7.99(\mathrm{~m}, 1 \mathrm{H}), 7.59(\mathrm{td}, 1 \mathrm{H}, J=7.4 \mathrm{~Hz}, 12 \mathrm{~Hz}), 7.46(\mathrm{td}$, $1 \mathrm{H}, J=7.7 \mathrm{~Hz}, 14 \mathrm{~Hz}), 7.48-7.41(\mathrm{~m}, 1 \mathrm{H}), 4.66(\mathrm{~d}, 1 \mathrm{H}, J=3.7 \mathrm{~Hz}), 4.37(\mathrm{q}, 2 \mathrm{H}, J=7.1 \mathrm{~Hz})$, $3.80(\mathrm{dd}, 1 \mathrm{H}, J=2.4 \mathrm{~Hz}, 11.8 \mathrm{~Hz}), 3.69-3.57$ (m, 2H), 3.52 (ddd, 1H, $J=2.3 \mathrm{~Hz}, 5.5 \mathrm{~Hz}, 9.9$ $\mathrm{Hz}), 3.40$ (s, 3H), 3.39-3.35 (m, 1H), 3.27-3.24 (m, 1H), 1.39 (t, 3H, $J=7.1 \mathrm{~Hz}) ;{ }^{13} \mathrm{C}$ NMR (125 MHz, $\left.\mathrm{CD}_{3} \mathrm{OD}\right) \delta=169.3,133.7,133.6,131.8,129.8,129.5,101.3,75.1,73.6,73.5,71.8$, 62.7, 62.6, 55.5, 14.5; ${ }^{11} \mathrm{~B}$ NMR (160 MHz, $\left.\mathrm{CD}_{2} \mathrm{Cl}_{2}\right) \delta=29.3$; HRMS (APCI+) calcd for [C ${ }_{16}$ $\left.{ }_{\text {h21 }} \mathrm{BO}_{8}+\mathrm{H}\right]^{+}:$353.14077, found: 353.1392 .

Methyl 2-O-acetyl- $\alpha$-D-glucopyranoside $(8 a),{ }^{[25]}$ methyl 3-O-acetyl- $\alpha$-D-glucopyranoside (9a), ${ }^{[25]}$ methyl 2,3-di- $O$-acetyl- $\alpha$-D-glucopyranoside $(10 a){ }^{[26]}$ and methyl 2,3,4,6-tetra- $O$ acetyl- $\alpha$-D-glucopyranoside. ${ }^{[27]}$ To a suspension of methyl $\alpha$-D-glucopyranoside (503 mg, $2.59 \mathrm{mmol}$ ) in toluene $(500 \mathrm{~mL})$, was added 2-ethoxycarbonylphenylboronic acid (554 mg, $2.86 \mathrm{mmol}, 1.10$ equiv.) and the reaction mixture was refluxed for $2 \mathrm{~h}$ using a Dean-Stark apparatus. The solution was then cooled down to room temperature and the solution was divided in 8 portions of $50 \mathrm{~mL}$ and used as it is for 8 reactions with different conditions. Solid $\mathrm{K}_{2} \mathrm{CO}_{3}$ was suspended in the previous solution $(357 \mathrm{mg}, 2.58 \mathrm{mmol}, 10.03$ equiv.) and a 0.05 M solution of DMAP in dry toluene $(0.30 \mathrm{~mL}, 0.015 \mathrm{mmol}, 0.05$ equiv. or $0.60 \mathrm{~mL}, 0.030$ mmol, 0.10 equiv.) was added dropwise followed by a $0.5 \mathrm{M}$ solution of acetic anhydride in dry toluene ( $0.6 \mathrm{~mL}, 0.30 \mathrm{mmol}, 1.17$ equiv. or $1.20 \mathrm{~mL}, 0.60 \mathrm{mmol}, 2.35$ equiv.). The reaction mixture was stirred for either $2 \mathrm{~h}$ or $16 \mathrm{~h}$ at room temperature under an argon atmosphere. Toluene was removed under vacuum and the crude materials from the 8 reactions combined were purified by silica gel column chromatography using a gradient eluent system (1-10\% $\mathrm{MeOH} / \mathrm{DCM})$ to obtain: 
Methyl 2- $O$-acetyl- $\alpha$-D-glucopyranoside 8a from a mixture as a colourless oil (57 $\mathrm{mg}, 9 \%$ yield). $\mathrm{R}_{f}=0.22$ (1:9 MeOH/DCM); IR (film, $\mathrm{CHCl}_{3}$ ) $v \max : 3339,2918,2842,2506,1647$, $1263,1193,1020,899,841,752,708,668 \mathrm{~cm}^{-1} ;{ }^{1} \mathrm{H}$ NMR $\left(300 \mathrm{MHz}, \mathrm{CD}_{3} \mathrm{OD}\right) \delta=4.83(\mathrm{~d}$, $1 \mathrm{H}, J=3.7 \mathrm{~Hz}), 4.57(\mathrm{dd}, 1 \mathrm{H}, J=3.7,10.0 \mathrm{~Hz}), 3.84-3.76(\mathrm{~m}, 2 \mathrm{H}), 3.71-3.65(\mathrm{~m}, 1 \mathrm{H}), 3.53$ (ddd, $1 \mathrm{H}, J=2.2,5.6,9.8 \mathrm{~Hz}), 3.39-3.32(\mathrm{~m}, 1 \mathrm{H}), 3.36(\mathrm{~s}, 3 \mathrm{H}), 2.08(\mathrm{~s}, 3 \mathrm{H}) ;{ }^{13} \mathrm{C}$ NMR $(75$ $\left.\mathrm{MHz}, \mathrm{CD}_{3} \mathrm{OD}\right) \delta=172.4,98.3,75.0,73.5,72.4,71.8,62.5,55.4,20.8$; HRMS (ESI+) calcd for $\left[\mathrm{C}_{9} \mathrm{H}_{16} \mathrm{O}_{7}+\mathrm{Na}\right]^{+}:$259.07937, found: 259.07883 .

Methyl 3-O-acetyl- $\alpha$-D-glucopyranoside 9a as a white solid (78 mg, 13\% yield). mp 142 $145^{\circ} \mathrm{C}\left(\mathrm{CHCl}_{3}\right) ;[\alpha]_{\mathrm{D}}^{22}=+281.8^{\circ}\left(c 0.3, \mathrm{CHCl}_{3}\right) ; \mathrm{R}_{f}=0.22(1: 9 \mathrm{MeOH} / \mathrm{DCM}) ; \mathrm{IR}$ (film, $\left.\mathrm{CHCl}_{3}\right) \vee \max : 3400,2914,1716,1430,1249,1190,1152,1046,908,843 \mathrm{~cm}^{-1}$; ${ }^{1} \mathrm{H}$ NMR $\left(300 \mathrm{MHz}, \mathrm{CDCl}_{3}\right) \delta=5.06(\mathrm{t}, 1 \mathrm{H}, J=9.3 \mathrm{~Hz}), 4.78(\mathrm{~d}, 1 \mathrm{H}, J=3.8 \mathrm{~Hz}), 3.91-3.81(\mathrm{~m}, 2 \mathrm{H})$, 3.70-3.57 (m, 3H), 3.45 (s, 3H), $2.16(\mathrm{~s}, 3 \mathrm{H}) ;{ }^{13} \mathrm{C} \mathrm{NMR}\left(300 \mathrm{MHz}, \mathrm{CD}_{3} \mathrm{OD}\right) \delta=173.8,102.1$, 78.1, 74.4, 72.8, 70.7, 63.3, 56.6, 22.1; HRMS (ESI+) calcd for $\left[\mathrm{C}_{9} \mathrm{H}_{16} \mathrm{O}_{7}+\mathrm{Na}\right]^{+}: 259.07937$, found: 259.07873 .

Methyl 2,3-di- $O$-acetyl- $\alpha$-D-glucopyranoside 10a $(262 \mathrm{mg}, 36 \%$ yield $)$. $[\alpha]_{\mathrm{D}}{ }^{22}=+111.1^{\circ}(c$ 1.0, $\mathrm{CHCl}_{3}$ ); $\mathrm{R}_{f}=0.38$ (1:9 MeOH/DCM); IR (film, $\mathrm{CHCl}_{3}$ ) v max: 3426, 2937, 1742, 1436, 1371, 1226, 1032, 919, $755 \mathrm{~cm}^{-1}$; ${ }^{1} \mathrm{H}$ NMR $\left(300 \mathrm{MHz}, \mathrm{CDCl}_{3}\right) \delta=5.34-5.23(\mathrm{~m}, 1 \mathrm{H}), 4.91(\mathrm{~d}$, $1 \mathrm{H}, J=3.6 \mathrm{~Hz}), 4.84(\mathrm{dd}, 1 \mathrm{H}, J=3.6 \mathrm{~Hz}, 10.1 \mathrm{~Hz}), 3.92-3.81(\mathrm{~m}, 2 \mathrm{H}), 3.75-3.67$ (m, 2H), 3.40, (s, 3H), 2.11 (s, 3H), 2.09 (s, 3H); ${ }^{13} \mathrm{C}$ NMR (125 MHz, $\left.\mathrm{CDCl}_{3}\right) \delta=172.0,170.3,96.8$, 73.5, 71.1, 70.7, 70.0, 62.0, 55.3, 20.9, 20.8; HRMS (ESI+) calcd for $\left[\mathrm{C}_{11} \mathrm{H}_{18} \mathrm{O}_{8}+\mathrm{Na}\right]^{+}$: 301.08994, found: 301.08957, literatureError! Bookmark not defined.: 301.0941.

And methyl 2,3,4,6-tetra- $O$-acetyl- $\alpha$-D-glucopyranoside as a colourless oil $(247 \mathrm{mg}, 26 \%$ yield). $[\alpha]_{\mathrm{D}}^{22}=+90.7^{\circ}\left(c 0.5, \mathrm{CHCl}_{3}\right) ; \mathrm{R}_{f}=0.72(1: 9 \mathrm{MeOH} / \mathrm{DCM})$; IR (film, $\left.\mathrm{CHCl}_{3}\right) v$ max: 2947, 1744, 1436, 1368, 1216, 1032, 930, 896, $755 \mathrm{~cm}^{-1} ;{ }^{1} \mathrm{H}$ NMR $\left(300 \mathrm{MHz}, \mathrm{CDCl}_{3}\right) \delta=$ $5.47(\mathrm{dd}, 1 \mathrm{H}, J=9.5 \mathrm{~Hz}, 10.0 \mathrm{~Hz}), 5.06(\mathrm{dd}, 1 \mathrm{H}, J=9.5 \mathrm{~Hz}, 10.1 \mathrm{~Hz}), 4.94(\mathrm{~d}, 1 \mathrm{H}, J=3.7$ $\mathrm{Hz}), 4.89(\mathrm{dd}, 1 \mathrm{H}, J=3.7 \mathrm{~Hz}, 10.1 \mathrm{~Hz}), 4.26(\mathrm{dd}, 1 \mathrm{H}, J=4.6 \mathrm{~Hz}, 12.3 \mathrm{~Hz}), 4.10(\mathrm{dd}, 1 \mathrm{H}, J=$ $2.3 \mathrm{~Hz}, 12.3 \mathrm{~Hz}$ ), 3.98 (ddd, 1H, J=2.3 Hz, 4.5 Hz, 10.2 Hz), 3.40 (s, 3H), 2.09 (s, 3H), 2.07 (s, 3H), 2.02 (s, 3H), $2.00(\mathrm{~s}, 3 \mathrm{H}) ;{ }^{1} \mathrm{H}$ NMR $\left(300 \mathrm{MHz}, \mathrm{CD}_{3} \mathrm{OD}\right) \delta=5.40(\mathrm{t}, 1 \mathrm{H}, J=9.5 \mathrm{~Hz})$, $5.02(\mathrm{t}, 1 \mathrm{H}, J=9.5 \mathrm{~Hz}$ ), $4.93(\mathrm{~d}, 1 \mathrm{H}, J=3.6 \mathrm{~Hz}), 4.84(\mathrm{dd}, 1 \mathrm{H}, J=3.6 \mathrm{~Hz}, 6.6 \mathrm{~Hz}), 4.25(\mathrm{dd}$, $1 \mathrm{H}, J=4.7 \mathrm{~Hz}, 12.3 \mathrm{~Hz}), 4.10(\mathrm{dd}, 1 \mathrm{H}, J=2.4 \mathrm{~Hz}, 12.3 \mathrm{~Hz}), 3.99(\mathrm{ddd}, 1 \mathrm{H}, J=2.4 \mathrm{~Hz}, 4.7$ $\mathrm{Hz}, 10.2 \mathrm{~Hz}), 3.41$ (s, 3H), 2.05 (s, 3H), 2.02 (s, 3H), 2.00 (s, 3H), 1.97 (s, 3H); ${ }^{13} \mathrm{C}$ NMR $\left(125 \mathrm{MHz}, \mathrm{CDCl}_{3}\right) \delta=170.7,170.1,170.0,169.6,96.75,70.8,70.1,68.5,67.1,61.9,55.5$, 20.7 (2C), 20.7, 20.6; HRMS (ESI+) calcd for $\left[\mathrm{C}_{15} \mathrm{H}_{22} \mathrm{O}_{10}+\mathrm{Na}\right]^{+}:$385.11107, found: 385.11054 . 
Methyl 4,6- $\boldsymbol{O}$-benzylidene- $\boldsymbol{\alpha}$-D-glucopyranoside (7). ${ }^{[19 \mathrm{a}]}$ Methyl $\alpha$-D-glucopyranoside $(1.010 \mathrm{~g}, 5.20 \mathrm{mmol})$ was suspended in acetonitrile $(20 \mathrm{~mL})$. A catalytic amount of solid $( \pm)$ camphorsulfonic acid (60 mg, $0.26 \mathrm{mmol}, 0.05$ equiv.) was added then benzaldehyde dimethyl acetal (1.4 mL, $9.33 \mathrm{mmol}, 2.5$ equiv.) was added. The reaction mixture was refluxed $20 \mathrm{~min}$ and monitored by TLC (9:1 EtOAc/Hexanes) until the majority of the starting material disappeared. The reaction mixture was cooled down to room temperature, neutralized with 2-3 drops of $\mathrm{Et}_{3} \mathrm{~N}$ (0.1 mL approx.) and the solvent evaporated under vacuum. The crude white solid was solubilized using a minimum of DCM (10 mL approx.), poured in an Erlenmeyer containing hexanes (40 mL approx.), crystallized and filtrated. The resulting white solid was purified by silica gel column chromatography using a gradient eluent system (10-90\% EtOAc/Hexanes) to obtain methyl 4,6-di- $O$-benzylidene- $\alpha$-D-glucopyranoside 7 as a white solid (1.069 g, 73\% yield). mp 159-161 ${ }^{\circ} \mathrm{C}\left(\mathrm{CHCl}_{3}\right) ;[\alpha]_{\mathrm{D}}^{22}=+116.7^{\circ}\left(c 1.0, \mathrm{CHCl}_{3}\right) ; \mathrm{R}_{f}$ $=0.31$ (90\% EtOAc/Hexanes); IR (film, $\mathrm{CHCl}_{3}$ ) v max: 3367, 2940, 2869, 1452, 1372, 1335, 1276, 1190, 1072, 1027, 997, 747, $695 \mathrm{~cm}^{-1}$; ${ }^{1} \mathrm{H}$ NMR (300 MHz, $\left.\mathrm{CDCl}_{3}\right) \delta=7.51-7.34(\mathrm{~m}$, $5 \mathrm{H}), 5.52(\mathrm{~s}, 1 \mathrm{H}), 4.77(\mathrm{~d}, 1 \mathrm{H}, J=3.9 \mathrm{~Hz}), 4.28(\mathrm{q}, 1 \mathrm{H}, J=3.4 \mathrm{~Hz}, 8.8 \mathrm{~Hz}), 3.91(\mathrm{t}, 1 \mathrm{H}, J=$ $9.2 \mathrm{~Hz}), 3.84-3.69(\mathrm{~m}, 2 \mathrm{H}), 3.61(\mathrm{~m}, 1 \mathrm{H}), 3.47(\mathrm{t}, 1 \mathrm{H}, J=9.2 \mathrm{~Hz}), 3.44(\mathrm{~s}, 3 \mathrm{H}) ;{ }^{13} \mathrm{C}$ NMR $\left(167 \mathrm{MHz}, \mathrm{CDCl}_{3}\right) \delta=137.0,129.2,128.3$ (2C), 126.3 (2C), 101.9, 99.8, 80.9, 72.8, 71.6, 68.9, 62.3, 55.; HRMS (ESI+) calcd for $\left[\mathrm{C}_{14} \mathrm{H}_{18} \mathrm{O}_{6}+\mathrm{Na}\right]^{+}: 305.10011$, found: 305.09934 .

Methyl 2-O-benzoyl-4,6- $O$-benzylidene- $\alpha$-D-glucopyranoside, ${ }^{[28]}$ methyl 3- $O$-benzoyl-4,6$O$-benzylidene- $\alpha$-D-glucopyranoside, and methyl 2,3-di- $O$-benzoyl-4,6- $O$-benzylidene- $\alpha$ D-glucopyranoside $^{[29]}$ Methyl 4,6-di- $O$-benzylidene- $\alpha$-D-glucopyranoside (506 mg, 1.79 mmol) was dissolved in dry toluene $(355 \mathrm{~mL})$ then solid $\mathrm{K}_{2} \mathrm{CO}_{3}$ was suspended (2.46 g, 17.8 mmol, 9.9 equiv.). A 0.05 M solution of DMAP in dry toluene $(1.8 \mathrm{~mL}, 0.09 \mathrm{mmol}, 0.05$ equiv.) was added dropwise followed by a $0.5 \mathrm{M}$ solution of benzoyl chloride in dry toluene ( $2.5 \mathrm{~mL}, 1.25 \mathrm{mmol}, 0.70$ equiv.). The reaction mixture was stirred overnight ( $16 \mathrm{~h}$ ) at room temperature under an argon atmosphere and monitored by TLC (3:7 $\mathrm{Et}_{2} \mathrm{O} /$ Toluene) until the majority of the starting material disappeared. Toluene was removed under vacuum and the crude material was dissolved in DCM then filtrated and concentrated in vacuum. The crude material was purified by silica gel column chromatography using a gradient eluent system (5$20 \% \mathrm{Et}_{2} \mathrm{O} /$ Toluene) to obtain methyl 2- $O$-benzoyl-4,6-di- $O$-benzylidene- $\alpha$-D-glucopyranoside as a white solid (38 mg, 5\% yield). $\mathrm{mp} 160-165^{\circ} \mathrm{C}\left(\mathrm{CHCl}_{3}\right) ;[\alpha]_{\mathrm{D}}{ }^{22}=+113.1^{\circ}\left(c 1.0, \mathrm{CHCl}_{3}\right)$; $\mathrm{R}_{f}=0.57$ (3:7 Et $2 \mathrm{O} /$ Toluene); IR (film, $\left.\mathrm{CHCl}_{3}\right) \vee \max : 3477,2935,2867,1717,1602,1585$, $1451,1377,1334,1316,1272,1177,1092,988,750,711 \mathrm{~cm}^{-1} ;{ }^{1} \mathrm{H}$ NMR $\left(300 \mathrm{MHz}, \mathrm{CDCl}_{3}\right) \delta$ $=8.12-7.38(\mathrm{~m}, 10 \mathrm{H}), 5.59(\mathrm{~s}, 1 \mathrm{H}), 5.08(\mathrm{t}, 1 \mathrm{H}, J=3.5 \mathrm{~Hz}), 5.03(\mathrm{q}, 1 \mathrm{H}, J=5.5 \mathrm{~Hz}), 4.40-$ $4.31(\mathrm{~m}, 2 \mathrm{H}), 3.97-3.89(\mathrm{~m}, 1 \mathrm{H}), 3.81(1,1 \mathrm{H}, J=10.1 \mathrm{~Hz}), 3.65(\mathrm{t}, 1 \mathrm{H}, J=9.3 \mathrm{~Hz}), 3.40(\mathrm{~s}$, $3 \mathrm{H}) ;{ }^{13} \mathrm{C}$ NMR $\left(167 \mathrm{MHz}, \mathrm{CDCl}_{3}\right) \delta=166.2,137.0,133.3,129.9$ (2C), 129.5, 129.3, 128.4 
(2C), 128.3 (2C), 126.3 (2C), 102.0, 97.7, 81.4, 74.1, 68.9, 68.8, 62.0, 55.5; HRMS (ESI+) calcd for $\left[\mathrm{C}_{21} \mathrm{H}_{22} \mathrm{O}_{7}+\mathrm{Na}\right]^{+}$: 409.12632, found: 409.12528 .

as well as methyl 3-O-benzoyl-4,6-di- $O$-benzylidene- $\alpha$-D-glucopyranoside in a mixture of mono- and disubstitued carbohydrates as a white solid (56 mg, $8 \%$ yield). $\mathrm{mp} 203-204^{\circ} \mathrm{C}$ $\left(\mathrm{CHCl}_{3}\right) ;[\alpha]_{\mathrm{D}}^{22}=+47.6^{\circ}\left(c 1.0, \mathrm{CHCl}_{3}\right) ; \mathrm{R}_{f}=0.41\left(3: 7 \mathrm{Et}_{2} \mathrm{O} /\right.$ Toluene); IR (film, $\left.\mathrm{CHCl}_{3}\right) v$ max: 3478, 2935, 2866, 1717, 1602, 1584, 1451, 1377, 1334, 1316, 1272, 1177, 1092, 988, 750, $711 \mathrm{~cm}^{-1}$; ${ }^{1} \mathrm{H} \mathrm{NMR}\left(300 \mathrm{MHz}, \mathrm{CDCl}_{3}\right) \delta=8.09-7.30(\mathrm{~m}, 10 \mathrm{H}), 5.59(\mathrm{t}, 1 \mathrm{H}, J=9.6 \mathrm{~Hz})$, $5.53(\mathrm{~s}, 1 \mathrm{H}), 4.86(\mathrm{~d}, 1 \mathrm{H}, J=3.8 \mathrm{~Hz}), 4.34(\mathrm{dd}, 1 \mathrm{H}, J=4.6 \mathrm{~Hz}, 10.0 \mathrm{~Hz}), 3.99-3.91(\mathrm{~m}, 1 \mathrm{H}$,$) ,$ 3.84-3.73 (m, 1H), $3.51(\mathrm{~s}, 3 \mathrm{H}) ;{ }^{13} \mathrm{C}$ NMR $\left(75 \mathrm{MHz}, \mathrm{CDCl}_{3}\right) \delta=166.6,136.9,133.1,129.9$ (2C), 129.0 (2C), 128.3 (2C), 128.2 (2C), 126.1 (2C), 101.5, 100.2, 78.8, 73.0, 72.0, 68.96, 62.8, 55.6; HRMS (ESI+) calcd for $\left[\mathrm{C}_{21} \mathrm{H}_{22} \mathrm{O}_{7}+\mathrm{Na}\right]^{+}$: 409.12632, found: 409.12493.

and methyl 2,3-di- $O$-benzoyl-4,6-di- $O$-benzylidene- $\alpha$-D-glucopyranoside (223 $\mathrm{mg}, 51 \%$ yield). mp 150-152 ${ }^{\circ} \mathrm{C}\left(\mathrm{CHCl}_{3}\right) ;[\alpha]_{\mathrm{D}}^{22}=+95.0^{\circ}\left(c 1.0, \mathrm{CHCl}_{3}\right) ; \mathrm{R}_{f}=0.83\left(3: 7 \mathrm{Et}_{2} \mathrm{O} /\right.$ Toluene); IR (film, $\mathrm{CHCl}_{3}$ ) v max: 2934, 2865, 1722, 1602, 1585, 1451, 1376, 1333, 1315, 1274, 1179, 1092, 991, 750, $708 \mathrm{~cm}^{-1} ;{ }^{1} \mathrm{H}$ NMR (300 MHz, $\left.\mathrm{CDCl}_{3}\right) \delta=8.01-7.31(\mathrm{~m}, 15 \mathrm{H}), 6.06(\mathrm{t}, 1 \mathrm{H}, J$ = $9.7 \mathrm{~Hz}), 5.57(\mathrm{~s}, 1 \mathrm{H}), 5.25(\mathrm{dd}, 1 \mathrm{H}, J=3.7 \mathrm{~Hz}, 9.9 \mathrm{~Hz}), 5.18(\mathrm{~d}, 1 \mathrm{H}, 3.7 \mathrm{~Hz}), 4.38(\mathrm{dd}, 1 \mathrm{H}$, $J=4.8 \mathrm{~Hz}, 10.2 \mathrm{~Hz}), 4.13-4.05(\mathrm{~m}, 1 \mathrm{H}), 3.89(\mathrm{q}, 2 \mathrm{H}, J=9.9 \mathrm{~Hz}, 21.4 \mathrm{~Hz}), 3.44(\mathrm{~s}, 3 \mathrm{H}) ;{ }^{13} \mathrm{C}$ $\operatorname{NMR}\left(167 \mathrm{MHz}, \mathrm{CDCl}_{3}\right) \delta=166.0,165.6,136.9$ (2C), 133.4, 133.0, 129.9 (2C), 129.7 (2C), 129.0 (2C), 128.4 (2C), 128.3 (2C), 128.2 (2C), 126.1 (2C), 101.6, 97.8, 79.4, 72.5, 69.5, 68.9, 62.5, 55.5; HRMS (ESI+) calcd for $\left[\mathrm{C}_{28} \mathrm{H}_{26} \mathrm{O}_{8}+\mathrm{Na}\right]^{+}: 513.15254$, found: 513.15058 .

Methyl 2-O-benzoyl- $\alpha$-D-glucopyranoside $\quad(\mathbf{8 b})^{[14 b]} \quad$ Methyl 2-O-benzoyl-4,6-di- $O$ benzylidene- $\alpha$-D-glucopyranoside ( $242 \mathrm{mg}, 0.81 \mathrm{mmol}$ ) was dissolved in methanol/DCM 6:1 $(7.0 \mathrm{~mL})$ and $10 \% \mathrm{w} / \mathrm{w} \mathrm{Pd} / \mathrm{C}(25 \mathrm{mg})$ was placed. The reaction mixture was bubbled with argon then stirred overnight $(16 \mathrm{~h})$ at room temperature under hydrogen atmosphere. The solution was filtrated on Celite ${ }^{\circledR}$, concentrated under vacuum and purified by silica gel column chromatography using a gradient eluent system (60-100\% EtOAc/Hexanes) to obtain methyl 2- $O$-benzoyl- $\alpha$-D-glucopyranoside $\mathbf{8 b}$ as a white solid (140 $\mathrm{mg}$, 75\% yield). mp 161$165^{\circ} \mathrm{C}\left(\mathrm{CHCl}_{3}\right) ;[\alpha]_{\mathrm{D}}^{22}=+96.5^{\circ}(c 1.0, \mathrm{MeOH}) ; \mathrm{R}_{f}=0.28$ (9:1 EtOAc/Hexanes); IR (film, $\mathrm{MeOH}) \vee \max : 3488,2929,1716,1602,1452,1276,1094,1027,909,713 \mathrm{~cm}^{-1}$; ${ }^{1} \mathrm{H}$ NMR $\left(300 \mathrm{MHz}, \mathrm{CDCl}_{3}\right) \delta=8.10-7.44(\mathrm{~m}, 5 \mathrm{H}), 5.03(\mathrm{~d}, 1 \mathrm{H}, J=3.7 \mathrm{~Hz}), 4.91(\mathrm{dd}, 1 \mathrm{H}, J=3.7 \mathrm{~Hz}$, $10.0 \mathrm{~Hz}), 4.15$ (dd, 1H, $J=8.7 \mathrm{~Hz}, 9.9 \mathrm{~Hz}), 3.96-3.85$ (m, 2H), 3.78-3.68 (m, 2H), 3.40 (s, $3 \mathrm{H}) ;{ }^{1} \mathrm{H}$ NMR $\left(300 \mathrm{MHz}, \mathrm{CD}_{3} \mathrm{OD}\right) \delta=8.09-7.45(\mathrm{~m}, 5 \mathrm{H}), 4.99(\mathrm{~d}, 1 \mathrm{H}, J=3.7 \mathrm{~Hz}), 4.83(\mathrm{dd}$, $1 \mathrm{H}, J=3.7 \mathrm{~Hz}, 10.0 \mathrm{~Hz}), 3.98(\mathrm{dd}, 1 \mathrm{H}, J=8.9 \mathrm{~Hz}, 9.9 \mathrm{~Hz}), 3.86(\mathrm{dd}, 1 \mathrm{H}, J=2.3 \mathrm{~Hz}, 11.8$ $\mathrm{Hz}), 3.73(\mathrm{dd}, 1 \mathrm{H}, J=5.5 \mathrm{~Hz}, 11.8 \mathrm{~Hz}), 3.65-3.59$ (m, 1H), 3.44 (dd, $1 \mathrm{H}, J=9.0 \mathrm{~Hz}, 9.8 \mathrm{~Hz}$ ), 3.38 (s, 3H); ${ }^{13} \mathrm{C}$ NMR (125 MHz, $\left.\mathrm{CD}_{3} \mathrm{OD}\right) \delta=168.6,135.3$ (2C), 131.7 (2C), 130.3 (2C), 
99.4, 76.4, 74.4, 73.3, 72.8, 63.4, 56.4; HRMS (ESI+) calcd for $\left[\mathrm{C}_{14} \mathrm{H}_{18} \mathrm{O}_{7}+\mathrm{Na}\right]^{+}:$321.09502, found: 321.09401 .

Methyl 3- $\boldsymbol{O}$-benzoyl-a-D-glucopyranoside $\quad(\mathbf{9 b})^{[30]}$ Methyl 3-O-benzoyl-4,6-di- $O$ benzylidene- $\alpha$-D-glucopyranoside (131 mg, $0.44 \mathrm{mmol}$ ) was dissolved in methanol/DCM 6:1 $(5.0 \mathrm{~mL})$ and $10 \% \mathrm{w} / \mathrm{w} \mathrm{Pd} / \mathrm{C}(14 \mathrm{mg})$ was placed. The reaction mixture was bubbled with argon then stirred overnight $(16 \mathrm{~h})$ at room temperature under hydrogen atmosphere. The solution was filtrated on Celite ${ }^{\circledR}$, concentrated under vacuum and purified by silica gel column chromatography using a gradient eluent system (60-100\% EtOAc/Hexanes) to obtain methyl 3- $O$-benzoyl- $\alpha$-D-glucopyranoside $\mathbf{9 b}$ as a white solid (73 $\mathrm{mg}, 72 \%$ yield). mp 151$155^{\circ} \mathrm{C}\left(\mathrm{CHCl}_{3}\right) ;[\alpha]_{\mathrm{D}}^{22}=+98.9^{\circ}(c$ 1.0, $\mathrm{MeOH}) ; \mathrm{R}_{f}=0.33$ (9:1 EtOAc/Hexanes); IR (film, $\left.\mathrm{CHCl}_{3}\right) \vee \max : 3420,2931,1706,1603,1451,1272,1125,1042,908,710 \mathrm{~cm}^{-1} ;{ }^{1} \mathrm{H}$ NMR $\left(300 \mathrm{MHz}, \mathrm{CDCl}_{3}\right) \delta=8.09-7.42(\mathrm{~m}, 5 \mathrm{H}), 5.31(\mathrm{dd}, 1 \mathrm{H}, J=8.9 \mathrm{~Hz}, 9.6 \mathrm{~Hz}), 4.84(\mathrm{~d}, 1 \mathrm{H}, J=$ $3.8 \mathrm{~Hz}), 3.94-3.71(\mathrm{~m}, 5 \mathrm{H}), 3.48$ (s, 3H); ${ }^{1} \mathrm{H}$ NMR (300 MHz, $\left.\mathrm{CD}_{3} \mathrm{OD}\right) \delta=8.10-7.45(\mathrm{~m}, 5 \mathrm{H})$, $5.43(\mathrm{dd}, 1 \mathrm{H}, J=8.8 \mathrm{~Hz}, 9.9 \mathrm{~Hz}), 4.77$ (d, $1 \mathrm{H}, J=3.7 \mathrm{~Hz}), 3.87-3.60(\mathrm{~m}, 5 \mathrm{H}), 3.47$ (s, 3H); ${ }^{13} \mathrm{C}$ NMR $\left(125 \mathrm{MHz}, \mathrm{CDCl}_{3}\right) \delta=168.1,133.5,129.9$ (2C), 129.5, 128.4 (2C), 99.4, 77.7, 71.4, 70.9, 69.4, 62.2, 55.5; HRMS (ESI+) calcd for $\left[\mathrm{C}_{14} \mathrm{H}_{18} \mathrm{O}_{7}+\mathrm{Na}\right]^{+}:$321.09502, found: 321.09418

Methyl 2,3-di-O-benzoyl-a-D-glucopyranoside (10b) ${ }^{[29]}$ Methyl 2,3-O-benzoyl-4,6-di- $O$ benzylidene- $\alpha$-D-glucopyranoside (315 $\mathrm{mg}, 0.78 \mathrm{mmol}$ ) was dissolved in methanol/DCM 3:1 $(8.0 \mathrm{~mL})$ and $10 \% \mathrm{w} / \mathrm{w} \mathrm{Pd} / \mathrm{C}(33 \mathrm{mg})$ was placed. The reaction mixture was bubbled with argon then stirred overnight $(16 \mathrm{~h})$ at room temperature under hydrogen atmosphere. The solution was filtrated on Celite ${ }^{\circledR}$, concentrated under vacuum and purified by silica gel column chromatography using a gradient eluent system (30-70\% EtOAc/Hexanes) to obtain methyl 2,3-di- $O$-benzoyl- $\alpha$-D-glucopyranoside 10b as a white solid (185 $\mathrm{mg}, 72 \%$ yield). $\mathrm{mp}$ $69-73^{\circ} \mathrm{C}\left(\mathrm{CHCl}_{3}\right) ;[\alpha]_{\mathrm{D}}{ }^{22}=+114.1^{\circ}(c 1.0, \mathrm{MeOH}) ; \mathrm{R}_{f}=0.71$ (9:1 EtOAc/Hexanes); IR (film, $\left.\mathrm{CHCl}_{3}\right) \vee \max : 3446,2936,1721,1602,1452,1277,1096,1027,915,709 \mathrm{~cm}^{-1} ;{ }^{1} \mathrm{H}$ NMR $\left(300 \mathrm{MHz}, \mathrm{CDCl}_{3}\right) \delta=7.99-7.34(\mathrm{~m}, 10 \mathrm{H}), 5.73(\mathrm{dd}, 1 \mathrm{H}, J=8.9 \mathrm{~Hz}, 10.1 \mathrm{~Hz}), 5.23(\mathrm{dd}, 1 \mathrm{H}$, $J=3.6 \mathrm{~Hz}, 10.1 \mathrm{~Hz}), 5.12(\mathrm{~d}, 1 \mathrm{H} J=3.6 \mathrm{~Hz}), 3.99-3.83(\mathrm{~m}, 4 \mathrm{H}), 3.43(\mathrm{~s}, 3 \mathrm{H}) ;{ }^{1} \mathrm{H}$ NMR $(300$ $\left.\mathrm{MHz}, \mathrm{CD}_{3} \mathrm{OD}\right) \delta=7.98-7.35(\mathrm{~m}, 10 \mathrm{H}), 5.81-5.74(\mathrm{~m}, 1 \mathrm{H}), 5.14-5.09(\mathrm{~m}, 2 \mathrm{H}), 3.92-3.74(\mathrm{~m}$, 4H), 3.46 (s, 3H); ${ }^{13} \mathrm{C}$ NMR (125 MHz, $\left.\mathrm{CDCl}_{3}\right) \delta=167.5,166.0,133.5$ (2C), 133.4 (2C), 129.9 (2C), 129.2 (2C), 129.1 (2C), 128.4 (2C), 97.1, 74.4, 71.4, 71.3, 70.0, 62.13, 55.4; HRMS (ESI+) calcd for $\left[\mathrm{C}_{21} \mathrm{H}_{22} \mathrm{O}_{8}+\mathrm{Na}\right]^{+}:$425.12124, found: 425.12005 .

Methyl 2-O-pivaloyl- $\alpha$-D-glucopyranoside $\quad(8 \mathrm{c}),{ }^{[31]} \quad$ methyl 3-O-pivaloyl- $\alpha$-Dglucopyranoside (9c) and methyl 2,3- $O$-di-pivaloyl- $\alpha$-D-glucopyranoside (10c). Methyl $\alpha$ D-glucopyranoside $(253 \mathrm{mg}, 1.30 \mathrm{mmol})$ was dissolved in dry toluene $(250 \mathrm{~mL})$ then solid 
$\mathrm{K}_{2} \mathrm{CO}_{3}$ was suspended (173 mg, $1.42 \mathrm{mmol}, 1.09$ equiv.). Four portions $0.05 \mathrm{M}$ solution of DMAP in dry toluene (1.3 mL, $0.07 \mathrm{mmol}, 0.05$ equiv.) were added dropwise (over 4 days) then four portions of $0.5 \mathrm{M}$ solution of benzoyl chloride in dry toluene $(2.8 \mathrm{~mL}, 1.40 \mathrm{mmol}$, 1.07 equiv.) were also added dropwise (over four days). The reaction mixture was stirred for 4 days at room temperature under argon atmosphere and monitored by TLC (1:9 $\mathrm{MeOH} / \mathrm{DCM}$ ) until the majority of the starting material disappeared. Toluene was removed under vacuum and the crude material was purified by silica gel column chromatography using a gradient eluent system (1-20\% $\mathrm{MeOH} / \mathrm{DCM})$ to obtain methyl 2- $O$-pivaloyl- $\alpha$-Dglucopyranoside $8 \mathbf{c}$ as a white solid $(257 \mathrm{mg}, 60 \%$ yield $) \mathrm{mp} 125-127^{\circ} \mathrm{C}\left(\mathrm{CDCl}_{3}\right) ;[\alpha]_{\mathrm{D}}{ }^{22}=$ $+150.3^{\circ}$ ( c 1.0, $\mathrm{CHCl}_{3}$ ); $\mathrm{R}_{f}=0.34(1: 9 \mathrm{MeOH} / \mathrm{DCM})$; . IR (film, $\mathrm{CHCl}_{3}$ ) v max: 3388, 2961, 2934, 1729, 1288, 1153, 1035, 912, 773, 707 $\mathrm{cm}^{-1} ;{ }^{1} \mathrm{H}$ NMR $\left(300 \mathrm{MHz}, \mathrm{CDCl}_{3}\right) \delta=4.87(\mathrm{~d}$, $1 \mathrm{H}, J=3.6 \mathrm{~Hz}), 4.64$ (dd, 1H, $J=3.6 \mathrm{~Hz}, 9.9 \mathrm{~Hz}), 3.97-3.80$ (m, 3H), 3.71-3.59 (m, 2H), 3.35 $(\mathrm{s}, 3 \mathrm{H}), 1.22(\mathrm{~s}, 9 \mathrm{H}) ;{ }^{1} \mathrm{H} \mathrm{NMR}\left(300 \mathrm{MHz}, \mathrm{CD}_{3} \mathrm{OD}\right) \delta=4.81(\mathrm{~d}, 1 \mathrm{H}, J=3.7 \mathrm{~Hz}), 4.53(\mathrm{dd}, 1 \mathrm{H}$, $J=3.7 \mathrm{~Hz}, 10.1 \mathrm{~Hz}), 3.85-3.77(\mathrm{~m}, 2 \mathrm{H}), 3.68(\mathrm{dd}, 1 \mathrm{H}, J=5.6 \mathrm{~Hz}, 11.9 \mathrm{~Hz}), 3.55(\mathrm{ddd}, 1 \mathrm{H}, J$ $=2.2 \mathrm{~Hz}, 5.5 \mathrm{~Hz}, 9.7 \mathrm{~Hz}), 3.39(\mathrm{~d}, 1 \mathrm{H}, J=4.8 \mathrm{~Hz}), 3.36(\mathrm{~s}, 3 \mathrm{H}), 1.21(\mathrm{~s}, 9 \mathrm{H}) ;{ }^{13} \mathrm{C}$ NMR $(125$ $\left.\mathrm{MHz}, \mathrm{CDCl}_{3}\right) \delta=178.7,97.2,73.1,71.7,70.9,70.1,61.5,55.4,38.9,27.0$ (3C); HRMS (ESI+) calcd for $\left[\mathrm{C}_{12} \mathrm{H}_{22} \mathrm{O}_{7}+\mathrm{Na}^{+}\right.$: 301.12631, found: 301.12591, literatureError!

Bookmark not defined.: 301.1277

and methyl 3-O-pivaloyl- $\alpha$-D-glucopyranoside $9 \mathrm{c}$ as a white solid (32 $\mathrm{mg}, 9 \%$ yield). mp 58$63^{\circ} \mathrm{C}\left(\mathrm{CDCl}_{3}\right) ;[\alpha]_{\mathrm{D}}^{22}=+198.2^{\circ}\left(c\right.$ 0.2, $\left.\mathrm{CHCl}_{3}\right) ; \mathrm{R}_{f}=0.41(1: 9 \mathrm{MeOH} / \mathrm{DCM})$; IR (film, $\left.\mathrm{CHCl}_{3}\right) \vee \max : 3421,2962,2933,1716,1286,1168,1046,909,769 \mathrm{~cm}^{-1} ;{ }^{1} \mathrm{H}$ NMR $(300 \mathrm{MHz}$, $\left.\mathrm{CDCl}_{3}\right) \delta=5.02(\mathrm{~s}, 1 \mathrm{H}), 4.79(\mathrm{~d}, 1 \mathrm{H}, J=3.8 \mathrm{~Hz}), 3.92-3.81(\mathrm{~m}, 2 \mathrm{H}), 3.71-3.60(\mathrm{~m}, 3 \mathrm{H}), 3.45$ $(\mathrm{s}, 3 \mathrm{H}), 1.25$ (s, 9H); ${ }^{1} \mathrm{H}$ NMR $\left(300 \mathrm{MHz}, \mathrm{CD}_{3} \mathrm{OD}\right) \delta=5.13(\mathrm{t}, 1 \mathrm{H}, J=9.6 \mathrm{~Hz}), 4.69$ (d, 1H, $J$ = $3.7 \mathrm{~Hz}), 3.80(\mathrm{dd}, 1 \mathrm{H}, J=2.3 \mathrm{~Hz}, 11.8 \mathrm{~Hz}), 3.68(\mathrm{dd}, 1 \mathrm{H}, J=5.1 \mathrm{~Hz}, 11.8 \mathrm{~Hz}), 3.59$ (ddd, $1 \mathrm{H}, J=2.2 \mathrm{~Hz}, 5.2 \mathrm{~Hz}, 9.8 \mathrm{~Hz}), 3.52(\mathrm{dd}, 1 \mathrm{H}, J=3.7 \mathrm{~Hz}, 10.0 \mathrm{~Hz}), 3.44-3.41(\mathrm{~m}, 1 \mathrm{H}), 3.43$ (s, 3H), $1.22(\mathrm{~s}, 9 \mathrm{H}) ;{ }^{13} \mathrm{C} \mathrm{NMR}\left(125 \mathrm{MHz}, \mathrm{CDCl}_{3}\right) \delta=180.6$, 99.3, 76.9, 71.4, 70.8, 69.4, 62.1, 55.4, 39.1, 27.1 (3C); HRMS (ESI+) calcd for $\left[\mathrm{C}_{12} \mathrm{H}_{22} \mathrm{O}_{7}+\mathrm{Na}\right]^{+}: 301.12632$, found: 301.1266 .

and methyl 2,3-O-di-pivaloyl- $\alpha$-D-glucopyranoside 10c as a white solid (53 $\mathrm{mg}, 21 \%$ yield). mp 96-98 ${ }^{\circ} \mathrm{C}\left(\mathrm{CDCl}_{3}\right) ;[\alpha]_{\mathrm{D}}^{21}=+113.3^{\circ}(c 0.9, \mathrm{MeOH}) ; \mathrm{R}_{f}=0.24$ (1:1 EtOAc/Hexanes); IR (film, $\mathrm{CHCl}_{3}$ ) $v$ max: 3450, 2969, 2935, 2875, 1735, 1482, 1284, 1158, 1045, 918, 771, 668 $\mathrm{cm}^{-1} ;{ }^{1} \mathrm{H}$ NMR $\left(300 \mathrm{MHz}, \mathrm{CD}_{3} \mathrm{OD}\right) \delta=5.34(\mathrm{dd}, 1 \mathrm{H}, J=8.9,10.2 \mathrm{~Hz}), 4.86(\mathrm{~d}, 1 \mathrm{H}, J=5.9$ $\mathrm{Hz}), 4.70(\mathrm{dd}, 1 \mathrm{H}, J=3.7,10.2 \mathrm{~Hz}), 3.82(\mathrm{dd}, 1 \mathrm{H}, J=2.0,11.8 \mathrm{~Hz}), 3.73-3.52(\mathrm{~m}, 3 \mathrm{H}), 3.39$ (s, 3H), 1.18 (s, 9H), 1.15 (s, 9H); ${ }^{13} \mathrm{C}$ NMR (75 MHz, CD $\left.{ }_{3} \mathrm{OD}\right) \delta=179.2,179.1,98.2,73.6$, 73.5, 72.7, 69.7, 62.1, 55.7, 39.8, 39.7, 27.6 (3C), 27.4 (3C); HRMS (ESI-) calcd for 
$\left[\mathrm{C}_{17} \mathrm{H}_{30} \mathrm{O}_{8}+\mathrm{Cl}\right]^{-}:$397.16292, found: 397.16306 . HRMS (ESI-) calcd for $\left[\mathrm{C}_{17} \mathrm{H}_{30} \mathrm{O}_{8}+\mathrm{HCOO}\right]^{-}$: 407.19172, found: 407.19151.

and methyl 2,3,4,6-O-tetra-pivaloyl- $\alpha$-D-glucopyranoside $\mathbf{1 0 d}$ as a white solid (22 $\mathrm{mg}, 6 \%$ yield). $\mathrm{mp} 87-89^{\circ} \mathrm{C}\left(\mathrm{CDCl}_{3}\right) ;[\alpha]_{\mathrm{D}}{ }^{21}=+80.0^{\circ}\left(c 1.0, \mathrm{CHCl}_{3}\right) ; \mathrm{R}_{f}=0.89(1: 1 \mathrm{EtOAc} /$ Hexanes $)$; IR (film, $\mathrm{CHCl}_{3}$ ) v max: 3364, 2974, 2493, 2070, 1737, 1481, 1282, 1124, 1036, 976, 922 , $895,762 \mathrm{~cm}^{-1}$; ${ }^{1} \mathrm{H}$ NMR $\left(300 \mathrm{MHz}, \mathrm{CD}_{3} \mathrm{OD}\right) \delta=5.49(\mathrm{t}, 1 \mathrm{H}, J=9.8 \mathrm{~Hz}), 5.12(\mathrm{t}, 1 \mathrm{H}, J=10.0$ $\mathrm{Hz}), 4.93(\mathrm{~d}, 1 \mathrm{H}, J=3.7), 4.80(\mathrm{dd}, 1 \mathrm{H}, J=3.7,10.1 \mathrm{~Hz}), 4.14(\mathrm{~s}, 1 \mathrm{H}), 4.13(\mathrm{~s}, 1 \mathrm{H}), 4.03(\mathrm{~m}$, $1 \mathrm{H}), 3.42(\mathrm{~s}, 3 \mathrm{H}), 1.11(\mathrm{~s}, 9 \mathrm{H}), 1.15(\mathrm{~s}, 18 \mathrm{H}), 1.12(\mathrm{~s}, 9 \mathrm{H}) ;{ }^{13} \mathrm{C} \mathrm{NMR}\left(75 \mathrm{MHz}, \mathrm{CD}_{3} \mathrm{OD}\right) \delta=$ 178.0, 179.1, 177.0, 176.4, 96.6, 71.0, 69.7, 67.7, 67.4, 61.6, 54.7, 38.5, 38.4 (2C), 38.3, 26.3 (3C), 26.2 (3C), 26.1 (3C), 26.0 (3C); HRMS (ESI+) calcd for $\left[\mathrm{C}_{27} \mathrm{H}_{46} \mathrm{O}_{10}+\mathrm{Na}\right]^{+}:$553.29887, found: 553.29760 .

n-Octyl 2-O-pivaloyl- $\beta$-D-glucopyranoside (14b). Two different experiments (A and B) where ran in two different round bottom flasks where $n$-octyl $\beta$-D-glucopyranoside (Experiment A: $1503 \mathrm{mg}, 5.14 \mathrm{mmol}$; Experiment B: $1502 \mathrm{mg}, 5.14 \mathrm{mmol}$ ) was suspended in toluene $(100 \mathrm{~mL})$ and was refluxed $1 \mathrm{~h}$ using a Dean-Stark apparatus. Then phenylboronic acid (Experiment A: $693 \mathrm{mg}, 5.68 \mathrm{mmol}, 1.11$ eq.) or 2-ethoxycarbonylphenylboronic acid (Experiment B: $1109 \mathrm{mg}, 5.72 \mathrm{mmol}, 1.11$ eq.) was added and the reaction mixture was again refluxed $1 \mathrm{~h}$ using a Dean-Stark apparatus. The solution was cooled down to room temperature then oven-dried $\mathrm{K}_{2} \mathrm{CO}_{3}$ (Experiment A: $7130 \mathrm{mg}, 51.59$ mmol, 10.04 eq.; Experiment B: 7119 mg, 51.51 mmol, 10.02 eq.) then PivCl (700 $\mu \mathrm{L}, 5.68 \mathrm{mmol}, 1.11$ eq.) were added. The reaction mixture was let stir $1 \mathrm{~h}$ at room temperature the oven-dried DMAP (Experiment A: $383 \mathrm{mg}, 3.14 \mathrm{mmol}, 0.61$ eq.; Experiment B: $379 \mathrm{mg}, 3.10 \mathrm{mmol}, 0.60$ eq.) was added and the reaction mixture was stirred $16 \mathrm{~h}$ at room temperature under argon atmosphere. The crude solution was filtered to remove $\mathrm{K}_{2} \mathrm{CO}_{3}$, toluene evaporated under vacuum and the combined crude materials (Experiment A and B) were purified by silica gel column chromatography using a gradient eluent system $(1-10 \% \mathrm{MeOH} / \mathrm{DCM})$ to obtain $n$-octyl 2- $O$-pivaloyl- $\beta$-Dglucopyranoside 14b as a colorless oil (106 mg, 3\% yield). $[\alpha]_{\mathrm{D}}^{22}=-24.2(\mathrm{c}=1.1, \mathrm{MeOH}) ; \mathrm{R}_{f}$ $=0.38(1: 9 \mathrm{MeOH} / \mathrm{DCM})$; IR (film, $\left.\mathrm{CHCl}_{3}\right) \vee \max : 3386,2927,1732,1281,1175,1151$, 1076, 1031, $755 \mathrm{~cm}^{-1}$; ${ }^{1} \mathrm{H}$ NMR $\left(500 \mathrm{MHz}, \mathrm{CD}_{3} \mathrm{OD}\right) \delta=4.67$ (at, $1 \mathrm{H}, J=8.1 \mathrm{~Hz}, 9.6 \mathrm{~Hz}$ ), $4.42(\mathrm{~d}, 1 \mathrm{H}, J=8.0 \mathrm{~Hz}), 3.85-3.89(\mathrm{~m}, 2 \mathrm{H}), 3.68(\mathrm{dd}, 1 \mathrm{H}, J=5.6 \mathrm{~Hz}, 12.0 \mathrm{~Hz}), 3.49$ (t, $1 \mathrm{H}, J$ $=8.7 \mathrm{~Hz}), 3.42-3.46(\mathrm{~m}, 1 \mathrm{H}), 3.35(\mathrm{t}, 1 \mathrm{H}, J=9.7 \mathrm{~Hz}), 3.31-3.27(\mathrm{~m}, 2 \mathrm{H}), 1.55-1.48(\mathrm{~m}, 2 \mathrm{H})$, $1.34-1.28(\mathrm{~m}, 9 \mathrm{H}), 1.21(\mathrm{~s}, 9 \mathrm{H}), 0.90-0.88(\mathrm{~m}, 3 \mathrm{H}) ;{ }^{13} \mathrm{C} \mathrm{NMR}\left(125 \mathrm{MHz}, \mathrm{CD}_{3} \mathrm{OD}\right) \delta=179.0$, 102.4, 78.0, 76.2, 75.0, 71.9, 70.6, 62.6, 39.9, 33.0, 30.8, 30.5. 30.4, 27.6, 27.2 (3C), 23.7, 14.4; HRMS (ESI+) calculated for $\left[\mathrm{C}_{19} \mathrm{H}_{36} \mathrm{O}_{7}+\mathrm{Na}\right]^{+}: 399.23587$, found: 399.23565 . 
$\boldsymbol{n}$-Octyl 3-O-pivaloyl- $\beta$-D-glucopyranoside (15b). Two different experiments (A and B) where ran in two different round bottom flasks where $n$-octyl $\beta$-D-glucopyranoside (Experiment A: $1503 \mathrm{mg}, 5.14 \mathrm{mmol}$; Experiment B: $1502 \mathrm{mg}, 5.14 \mathrm{mmol}$ ) was suspended in toluene $(100 \mathrm{~mL})$ and was refluxed $1 \mathrm{~h}$ using a Dean-Stark apparatus. Then phenylboronic acid (Experiment A: $693 \mathrm{mg}, 5.68 \mathrm{mmol}, 1.11 \mathrm{eq}$.) or 2-ethoxycarbonylphenylboronic acid (Experiment B: $1109 \mathrm{mg}, 5.72 \mathrm{mmol}, 1.11 \mathrm{eq}$.) was added and the reaction mixture was again refluxed $1 \mathrm{~h}$ using a Dean-Stark apparatus. The solution was cooled down to room temperature then oven-dried $\mathrm{K}_{2} \mathrm{CO}_{3}$ (Experiment A: $7130 \mathrm{mg}, 51.59$ mmol, 10.04 eq.; Experiment B: 7119 mg, 51.51 mmol, 10.02 eq.) then PivCl (700 $\mu \mathrm{L}, 5.68 \mathrm{mmol}, 1.11$ eq.) were added. The reaction mixture was let stir $1 \mathrm{~h}$ at room temperature the oven-dried DMAP (Experiment A: $383 \mathrm{mg}$, $3.14 \mathrm{mmol}, 0.61$ eq.; Experiment B: $379 \mathrm{mg}, 3.10 \mathrm{mmol}, 0.60$ eq.) was added and the reaction mixture was stirred $16 \mathrm{~h}$ at room temperature under argon atmosphere. The crude solution was filtered to remove $\mathrm{K}_{2} \mathrm{CO}_{3}$, toluene evaporated under vacuum and the combined crude materials (Experiment A and B) were purified by silica gel column chromatography using a gradient eluent system (1-10\% $\mathrm{MeOH} / \mathrm{DCM})$ to obtain $n$-octyl 3- $O$-pivaloyl- $\beta$-Dglucopyranoside $15 \mathrm{~b}$ as a colorless oil $(117 \mathrm{mg}, 3 \%$ yield $) .[\alpha]_{\mathrm{D}}^{22}=+8.3(\mathrm{c}=0.3, \mathrm{MeOH}) ; \mathrm{R}_{f}=$ 0.55 (1:9 MeOH/DCM); IR (film, $\mathrm{CHCl}_{3}$ ) v max: 3442, 2926, 1732, 1280, 1178, 1158, 1057, $1031,765 \mathrm{~cm}^{-1} .{ }^{1} \mathrm{H}$ NMR $\left(500 \mathrm{MHz}, \mathrm{CD}_{3} \mathrm{OD}\right) v=4.90(\mathrm{t}, 1 \mathrm{H}, J=9.5 \mathrm{~Hz}), 4.31(\mathrm{~d}, 1 \mathrm{H}, J=$ $7.8 \mathrm{~Hz}), 3.92-3.88(\mathrm{~m}, 1 \mathrm{H}), 3.85(\mathrm{dd}, 1 \mathrm{H}, J=2.3 \mathrm{~Hz}, 11.9 \mathrm{~Hz}), 3.68(\mathrm{dd}, 1 \mathrm{H}, J=5.5 \mathrm{~Hz}, 11.9$ $\mathrm{Hz}), 3.56-3.52(\mathrm{~m}, 1 \mathrm{H}), 3.44(\mathrm{t}, 1 \mathrm{H}, J=9.6 \mathrm{~Hz}), 3.34-3.26(\mathrm{~m}, 2 \mathrm{H}), 1.64-1.58(\mathrm{~m}, 2 \mathrm{H}), 1.41-$ $1.26(\mathrm{~m}, 10 \mathrm{H}), 1.23(\mathrm{~s}, 9 \mathrm{H}), 0.91-0.88(\mathrm{~m}, 3 \mathrm{H}) ;{ }^{13} \mathrm{C} \mathrm{NMR}\left(125 \mathrm{MHz}, \mathrm{CD}_{3} \mathrm{OD}\right) \delta=179.9$, 104.4, 78.6, 77.9, 73.5, 71.0, 69.8, 62.4, 39.9, 33.0, 30.8, 30.6. 30.4, 27.6, 27.1 (3C), 23.7, 14.4; HRMS (ESI+) calculated for $\left[\mathrm{C}_{19} \mathrm{H}_{36} \mathrm{O}_{7}+\mathrm{Na}\right]^{+}: 399.23587$, found: 399.23569 .

$\boldsymbol{n}$-Octyl 2,3-O-pivaloyl- $\beta$-D-glucopyranoside (16b). Two different experiments (A and B) where ran in two different round bottom flasks where $n$-octyl $\beta$-D-glucopyranoside (Experiment A: $1503 \mathrm{mg}, 5.14 \mathrm{mmol}$; Experiment B: $1502 \mathrm{mg}, 5.14 \mathrm{mmol}$ ) was suspended in toluene $(100 \mathrm{~mL})$ and was refluxed $1 \mathrm{~h}$ using a Dean-Stark apparatus. Then phenylboronic acid (Experiment A: $693 \mathrm{mg}, 5.68 \mathrm{mmol}, 1.11 \mathrm{eq}$.) or 2-ethoxycarbonylphenylboronic acid (Experiment B: $1109 \mathrm{mg}, 5.72 \mathrm{mmol}, 1.11 \mathrm{eq}$.) was added and the reaction mixture was again refluxed $1 \mathrm{~h}$ using a Dean-Stark apparatus. The solution was cooled down to room temperature then oven-dried $\mathrm{K}_{2} \mathrm{CO}_{3}$ (Experiment A: $7130 \mathrm{mg}, 51.59 \mathrm{mmol}, 10.04$ eq.; Experiment B: $7119 \mathrm{mg}, 51.51 \mathrm{mmol}, 10.02$ eq.) then $\mathrm{PivCl}(700 \mu \mathrm{L}, 5.68 \mathrm{mmol}, 1.11$ eq.) were added. The reaction mixture was let stir $1 \mathrm{~h}$ at room temperature the oven-dried DMAP (Experiment A: 383 mg, 3.14 mmol, 0.61 eq.; Experiment B: 379 mg, $3.10 \mathrm{mmol}, 0.60$ eq.) was added and the reaction mixture was stirred $16 \mathrm{~h}$ at room temperature under argon atmosphere. The crude solution was filtered to remove $\mathrm{K}_{2} \mathrm{CO}_{3}$, toluene evaporated under 
vacuum and the combined crude materials (Experiment A and B) were purified by silica gel column chromatography using a gradient eluent system (1-10\% $\mathrm{MeOH} / \mathrm{DCM})$ to obtain $n$ octyl 2,3-di- $O$-pivaloyl- $\beta$-D-glucopyranoside $\mathbf{1 6 b}$ as a colorless oil (68 $\mathrm{mg}, 1 \%$ yield). [ $\alpha]_{\mathrm{D}}{ }^{22}$ $=-53.4(\mathrm{c}=0.3, \mathrm{MeOH}) ; \mathrm{R}_{f}=0.61(1: 9 \mathrm{MeOH} / \mathrm{DCM}) ; \mathrm{IR}\left(\right.$ film, $\left.\mathrm{CHCl}_{3}\right) \vee \max : 3476,2930$, $1738,1316,1182,1150,1089,1033,762 \mathrm{~cm}^{-1},{ }^{1} \mathrm{H}$ NMR $\left(500 \mathrm{MHz}, \mathrm{CD}_{3} \mathrm{OD}\right) \delta=5.08(\mathrm{t}, 1 \mathrm{H}$, $J=9.5 \mathrm{~Hz}), 4.79($ at, $1 \mathrm{H}, J=8.0 \mathrm{~Hz}, 9.8 \mathrm{~Hz}), 4.55(\mathrm{~d}, 1 \mathrm{H}, J=8.0 \mathrm{~Hz}), 3.91-3.85(\mathrm{~m}, 2 \mathrm{H})$, $3.70(\mathrm{dd}, 1 \mathrm{H}, J=5.4 \mathrm{~Hz}, 12.0 \mathrm{~Hz}), 3.55(\mathrm{t}, 1 \mathrm{H}, J=9.6 \mathrm{~Hz}), 3.50-3.45(\mathrm{~m}, 1 \mathrm{H}), 3.38$ (ddd, $1 \mathrm{H}$, $J=2.3 \mathrm{~Hz}, 5.4 \mathrm{~Hz}, 9.9 \mathrm{~Hz}), 1.56-1.48$ (m, 2H), 1.40-1.26 (m, 10H), $1.16(\mathrm{~s}, 9 \mathrm{H}), 1.15$ (s, 9H), 0.90-0.87 (m, 3H); ${ }^{13} \mathrm{C}$ NMR (125 MHz, $\left.\mathrm{CD}_{3} \mathrm{OD}\right) \delta=179.1,178.4,102.1,78.0,76.3,73.1$, 70.8, 69.7, 62.2, 39.9, 39.8, 33.0, 30.8, 30.5, 30.4, 27.6 (6C), 27.3, 23.7, 14.4; HRMS (ESI+) calculated for $\left[\mathrm{C}_{24} \mathrm{H}_{44} \mathrm{O}_{8}+\mathrm{Na}\right]^{+}: 483.29339$, found: 483.29347 .

Methyl 2-O-pivaloyl-a-D-galactopyranoside (17b). Two different experiments (A and B) where ran in two different round bottom flasks where methyl $\alpha$-D-galactopyranoside (Experiment A: $1004 \mathrm{mg}, 5.17 \mathrm{mmol}$; Experiment B: $1004 \mathrm{mg}, 5.17 \mathrm{mmol}$ ) was suspended in toluene $(100 \mathrm{~mL})$ and was refluxed $1 \mathrm{~h}$ using a Dean-Stark apparatus. Then phenylboronic acid (Experiment A: $707 \mathrm{mg}, 5.80 \mathrm{mmol}, 1.12$ eq.) or 2-ethoxycarbonylphenylboronic acid (Experiment B: $1100 \mathrm{mg}, 5.67 \mathrm{mmol}, 1.10$ eq.) was added and the reaction mixture was again refluxed $1 \mathrm{~h}$ using a Dean-Stark apparatus. The solution was cooled down to room temperature then oven-dried $\mathrm{K}_{2} \mathrm{CO}_{3}$ (Experiment A: $7165 \mathrm{mg}, 51.84 \mathrm{mmol}, 10.03$ eq.; Experiment B: $7126 \mathrm{mg}, 51.56 \mathrm{mmol}, 9.97$ eq.) then $\mathrm{PivCl}(700 \mu \mathrm{L}, 5.68 \mathrm{mmol}, 1.10$ eq.) were added. The reaction mixture was let stir $1 \mathrm{~h}$ at room temperature the oven-dried DMAP (Experiment A: $382 \mathrm{mg}, 3.13$ mmol, 0.60 eq.; Experiment B: $383 \mathrm{mg}, 3.14 \mathrm{mmol}, 0.61$ eq.) was added and the reaction mixture was stirred $16 \mathrm{~h}$ at room temperature under argon atmosphere. The crude solution was filtered to remove $\mathrm{K}_{2} \mathrm{CO}_{3}$, toluene evaporated under vacuum and the combined crude materials (Experiment $\mathrm{A}$ and $\mathrm{B}$ ) were purified by silica gel column chromatography using a gradient eluent system (1-10\% MeOH/DCM), solubilized into EtOAc then crystallized into $n$-pentane to obtain methyl 2- $O$-pivaloyl- $\alpha$-Dglucopyranoside $\mathbf{1 7 b}$ as a colorless oil $(116 \mathrm{mg}, 4 \%$ yield $)$. mp $111-114^{\circ} \mathrm{C}$ (Pentane); $[\alpha]_{\mathrm{D}}{ }^{22}=$ +173.7 (c=1.0, MeOH); $\mathrm{R}_{f}=0.42$ (1:9 MeOH/DCM); IR (film, $\mathrm{CHCl}_{3}$ ) v max: 3420, 2961, 1727, 1289, 1171, 1145, 1047, 914, $774 \mathrm{~cm}^{-1} ;{ }^{1} \mathrm{H}$ NMR $\left(500 \mathrm{MHz}, \mathrm{CD}_{3} \mathrm{OD}\right) \delta=4.91(\mathrm{dd}, 1 \mathrm{H}$, $J=3.8 \mathrm{~Hz}, 9.7 \mathrm{~Hz}), 4.85(\mathrm{~d}, 1 \mathrm{H}, 3.9 \mathrm{~Hz}), 3.94-3.91(\mathrm{~m}, 2 \mathrm{H}), 3.81-3.78(\mathrm{~m}, 1 \mathrm{H}), 3.75-3.67(\mathrm{~m}$, 2H), $3.35(\mathrm{~s}, 3 \mathrm{H}), 1.21(\mathrm{~s}, 9 \mathrm{H}) ;{ }^{13} \mathrm{C} \mathrm{NMR}\left(125 \mathrm{MHz}, \mathrm{CD}_{3} \mathrm{OD}\right) \delta=180.0,98.6,72.6,72.2$, 71.3, 68.9, 62.7, 55.7, 39.8, 27.5 (3C); HRMS (ESI+) calculated for $\left[\mathrm{C}_{12} \mathrm{H}_{22} \mathrm{O}_{7}+\mathrm{Na}\right]^{+}$: 301.12632, found: 301.12588 . 
Methyl 3-O-pivaloyl-a-D-galactopyranoside (18b). Two different experiments (A and B) where ran in two different round bottom flasks where methyl $\alpha$-D-galactopyranoside (Experiment A: $1004 \mathrm{mg}, 5.17 \mathrm{mmol}$; Experiment B: $1004 \mathrm{mg}, 5.17 \mathrm{mmol}$ ) was suspended in toluene $(100 \mathrm{~mL})$ and was refluxed $1 \mathrm{~h}$ using a Dean-Stark apparatus. Then phenylboronic acid (Experiment A: $707 \mathrm{mg}, 5.80 \mathrm{mmol}, 1.12$ eq.) or 2-ethoxycarbonylphenylboronic acid (Experiment B: $1100 \mathrm{mg}, 5.67 \mathrm{mmol}, 1.10$ eq.) was added and the reaction mixture was again refluxed $1 \mathrm{~h}$ using a Dean-Stark apparatus. The solution was cooled down to room temperature then oven-dried $\mathrm{K}_{2} \mathrm{CO}_{3}$ (Experiment A: $7165 \mathrm{mg}, 51.84$ mmol, 10.03 eq.; Experiment B: 7126 mg, $51.56 \mathrm{mmol}, 9.97$ eq.) then $\mathrm{PivCl}(700 \mu \mathrm{L}, 5.68 \mathrm{mmol}, 1.10$ eq.) were added. The reaction mixture was let stir $1 \mathrm{~h}$ at room temperature the oven-dried DMAP (Experiment A: $382 \mathrm{mg}, 3.13 \mathrm{mmol}, 0.60$ eq.; Experiment B: $383 \mathrm{mg}, 3.14 \mathrm{mmol}, 0.61$ eq.) was added and the reaction mixture was stirred $16 \mathrm{~h}$ at room temperature under argon atmosphere. The crude solution was filtered to remove $\mathrm{K}_{2} \mathrm{CO}_{3}$, toluene evaporated under vacuum and the combined crude materials (Experiment A and B) were purified by silica gel column chromatography using a gradient eluent system $(1-10 \% \mathrm{MeOH} / \mathrm{DCM})$, solubilized into EtOAc then crystallized into $n$-pentane to obtain methyl 3-O-pivaloyl- $\alpha$-D-glucopyranoside $\mathbf{1 8 b}$ as a colorless oil (39 mg, $1 \%$ yield). $[\alpha]_{\mathrm{D}}{ }^{22}=+156.6(\mathrm{c}=0.4, \mathrm{MeOH}) ; \mathrm{R}_{f}=0.48(1: 9 \mathrm{MeOH} / \mathrm{DCM})$; IR (film, $\mathrm{CHCl}_{3}$ ) $v$ max: 3433, 2962, 1713, 1314, 1284, 1147, 1049, 918, $753 \mathrm{~cm}^{-1} .{ }^{1} \mathrm{H}$ NMR $\left(500 \mathrm{MHz}, \mathrm{CD}_{3} \mathrm{OD}\right) \delta=4.92(\mathrm{dd}, 1 \mathrm{H}, J=3.2 \mathrm{~Hz}, 10.6 \mathrm{~Hz}), 4.74(\mathrm{~d}, 1 \mathrm{H}, 3.8 \mathrm{~Hz}), 4.03-4.00$ (m, 2H), 3.82-3.80 (m, 1H), 3.75-3.64 (m, 2H), $3.43(\mathrm{~s}, 3 \mathrm{H}), 1.23(\mathrm{~s}, 9 \mathrm{H}) ;{ }^{13} \mathrm{C}$ NMR $(125$ $\left.\mathrm{MHz}, \mathrm{CD}_{3} \mathrm{OD}\right) \delta=180.0,101.6,74.5,72.1,68.6,62.5,55.7,40.0,27.6$ (3C); HRMS (ESI+) calculated for $\left[\mathrm{C}_{12} \mathrm{H}_{22} \mathrm{O}_{7}+\mathrm{Na}\right]^{+}: 301.12632$, found: 301.12622 .

X-ray crystallography and NMR spectroscopy. The procedure is that used and reported in ${ }^{[32]}$. Crystal structures of $\mathbf{5 a}, \mathbf{5 b}$ and $\mathbf{8 c}$ have been obtained and the three structures have been submitted to the Cambridge Crystallographic Data Centre. CCDC codes: 1439240, 1439241 and 1492626.

Computational chemistry. A conformational search was carried out using in-house software to generate a large number of conformers, then using semi-empirical techniques (RM1) to optimize the geometry of these conformers and finally more accurately using DFT, more specifically the M06 functional (restricted Hartree-Fock) with the $6-31+\mathrm{G}^{*}$ basis set. All calculations were done using a PCM (Polarizable Continuum Model) solvent model (toluene). The semi-empirical and DFT calculations were performed using GAMESS-US v.Aug201164bit. The optimal conformation was then converted into a Z-matrix and the relevant C-O bonds were rotated at $10^{\circ}$ intervals. At each rotation, single point energies were calculated 
using the DFT conditions mentioned above. The minimum-energy structures are given as supporting information as Z-matrices along with the QM-energies (hartree).

\section{Acknowledgements}

We acknowledge Natural Sciences and Engineering Research Council of Canada (NSERC) for financial support as well as Profs Bohle and Rogers for the crystallography studies.

[1] a) R. Roy, Drug Discov. Today Technol. 2004, 1, 327-336; b) R. Hevey, C. C. Ling, Future Med. Chem. 2012, 4, 545-584.

[2] a) J. M. Walengaa, W. P. Jeskeb, F. X. Frapaisec, R. L. Bickd, J. Fareede, M. M. Samamae, Expert Opin. Invest. Drugs 2002, 11, 397-407; b) M. Petitou, P. Duchaussoy, J.-M. Herbert, G. Duc, M. El Hajji, J.-F. Branellec, F. Donat, J. Necciari, R. Cariou, J. Bouthier, E. Garrigou, Semin. Thromb. Hemost. 2002, 28, 393-402.

[3] A. Fernández-Tejada, F. J. Cañada, J. Jiménez-Barbero, Chem. Eur. J. 2015.

[4] a) S. S. Shivatare, S. H. Chang, T. I. Tsai, C. T. Ren, H. Y. Chuang, L. Hsu, C. W. Lin, S. T. Li, C. Y. Wu, C. H. Wong, J. Am. Chem. Soc. 2013, 135, 15382-15391; b) R. M. Wilson, S. J. Danishefsky, J. Am. Chem. Soc. 2013, 135, 14462-14472.

[5] V. Verez-Bencomo, V. Fernández-Santana, E. Hardy, M. E. Toledo, M. C. Rodriguez, L. Heynngnezz, A. Rodriguez, A. Baly, L. Herrera, M. Izquierdo, A. Villar, Y. Valdés, K. Cosme, M. L. Deler, M. Montane, E. Garcia, A. Ramos, A. Aguilar, E. Medina, G. Toraño, I. Sosa, I. Hernandez, R. Martínez, A. Muzachio, A. Carmenates, L. Costa, F. Cardoso, C. Campa, M. Diaz, R. Roy, Science 2004, 305, 522-525.

[6] M. Jager, A. J. Minnaard, Chem. Comm. 2016, Advance article.

[7] K. S. Griswold, S. J. Miller, Tetrahedron 2003, 59, 8869-8875.

[8] T. Kawabata, W. Muramatsu, T. Nishio, T. Shibata, Y. Uruno, R. Stragies, Synthesis 2008, 747-753.

[9] a) T. Kawabata, W. Muramatsu, T. Nishio, T. Shibata, H. Schedel, J. Am. Chem. Soc. 2007, 129, 12890-12895 ; b) T. Kawabata, T. Furuta, Chem. Lett. 2009, 38, 640-647; c) Y. Ueda, W. Muramatsu, K. Mishiro, T. Furuta, T. Kawabata, J. Org. Chem. 2009, 74, 8802-8805; d) W. Muramatsu, K. Mishiro, Y. Ueda, T. Furuta, T. Kawabata, Eur. J. Org. Chem. 2010, 827-831.

[10] a) Y. Ueda, K. Mishiro, K. Yoshida, T. Furuta, T. Kawabata, J. Org. Chem. 2012, 77, 7850-7857; b) H. Takeuchi, K. Mishiro, Y. Ueda, Y. Fujimori, T. Furuta, T. Kawabata, Angew. Chem. Int. Ed. 2015, 54, 6177-6180.

[11] K. Oshima, E.-i. Kitazono, Y. Aoyama, Tetrahedron Lett. 1997, 38, 5001-5004.

[12] K. Oshima, Y. Aoyama, J. Am. Chem. Soc. 1999, 121, 2315-2316. 
[13] a) C. Gouliaras, D. Lee, L. Chan, M. S. Taylor, J. Am. Chem. Soc. 2011, 133, 1392613929; b) D. Lee, C. L. Williamson, L. Chan, M. S. Taylor, J. Am. Chem. Soc. 2012, 134, 8260-8267.

[14] a) M. Giordano, A. Iadonisi, J. Org. Chem. 2014, 79, 213-222; b) Y. Demizu, Y. Kubo, H. Miyoshi, T. Maki, Y. Matsumura, N. Moriyama, O. Onomura, Org. Lett. 2008, 10, 5075-5077.

[15] a) H. L. M. Pekelharing, A. G. Lemmens, A. C. Beynen, Br. J. Nutr. 1994, 71, 103-109; b) C. A. Sousa, M. Ramiro Pastorinho, S. Takahashi, S. Tanabe, Environ. Chem. Lett. 2014, 12, 117-137.

[16] E. V. Evtushenko, Carbohydr. Res. 2012, 359, 111-119.

[17] Y. Bourdreux, A. Lemétais, D. Urban, J. M. Beau, Chem. Comm. 2011, 47, 2146-2148.

[18] J. Lawandi, S. Rocheleau, N. Moitessier, Tetrahedron 2016, 72, 6283-6319.

[19] a) N. Moitessier, P. Englebienne, Y. Chapleur, Tetrahedron 2005, 61, 6839-6853; b) J. Lawandi, S. Rocheleau, N. Moitessier, Tetrahedron 2011, 67, 8411-8420.

[20] C. A. McClary, M. S. Taylor, Carbohydr. Res. 2013, 381, 112-122.

[21] P. T. Anastas, J. C. Warner, Green Chemistry: Theory and Practice, , Oxford University Press, New York, 1998.

[22] R. J. Ferrier, D. Prasad, J. Chem. Soc. 1965, 7429-7432.

[23] a) E. Kaji, T. Nishino, K. Ishige, Y. Ohya, Y. Shirai, Tetrahedron Lett. 2010, 51, 15701573; b) T. H. Fenger, R. Madsen, Eur. J. Org. Chem. 2013, 5923-5933.

[24] M. Meiland, T. Heinze, W. Guenther, T. Liebert, Tetrahedron Lett. 2009, 50, 469-472.

[25] A. R. Moen, T. Anthonsen, Biocatal. Biotransfor. 2009, 27, 226-236.

[26] P. S. Sumar, G. D. K. Kumar, S. Baskaran, Eur. J. Org. Chem. 2008, 6063-6067.

[27]a) A. Sakakura, K. Kawajiri, T. Ohkubo, Y. Kosugi, K. Ishihara, J. Am. Chem. Soc. 2007, 129, 14775-14779; b) Z. D. Wang, Y. Mo, C.-L. Chiou, M. Liu, Molecules 2010, 15, 374-384.

[28] M. Adinolfi, A. Iadonisi, A. Pastore, Tetrahedron Lett. 2009, 50, 7051-7054.

[29] K. Michigami, M. Hayashi, Tetrahedron 2013, 69, 4221-4225.

[30] a) J. J. Willard, J. Sadowski, W. Vitale, Can. J. Chem. 1963, 41, 1223-1230; b) G. N. Bollenback, F. W. Parrish, Carbohydr. Res. 1971, 17, 431-438.

[31] M. Heuckendorff, C. M. Pedersen, M. Bols, Org. Lett. 2011, 13, 5956-5959.

[32] G. Mariaule, S. De Cesco, F. Airaghi, J. Kurian, P. Schiavini, S. Rocheleau, I. Huskić, K. Auclair, A. Mittermaier, N. Moitessier, J. Med. Chem. 2016, 59, 4221-4234. 